\title{
Determinantes do Risco de Crédito Rural no Brasil: Uma Crítica às Renegociações da Dívida Rural
}

\author{
Lucas Braga de Melo* \\ Moisés de Andrade Resende Filho ${ }^{\dagger}$
}

\author{
Sumário: 1. Introdução; 2. A Política de Crédito Rural no Brasil; 3. Fundamentação Teórica e Modelo \\ Econométrico; 4. Dados, Construção e Descrição das Variáveis e Seus Efeitos Esperados; \\ 5. Estratégia de Estimação e Discussao dos Resultados; 6. Conclusões. \\ Palavras-chave: Default Rate, Rural Credit, ARLD Bounds Testing Approach, Cointegration, Moral Hazard, \\ Adverse Selection. \\ Códigos JEL: $\quad$ G3, G32, G38.
}

Identificamos os determinantes da inadimplência no Sistema Nacional de Crédito Rural do Brasil, utilizando o procedimento ARDL defasagens distribuídas testes de limites para cointegração de Pesaran, Shin \& Smith (2001) e testes de causalidade de Granger de Toda \& Yamamoto (1995). Os resultados mostraram que taxa de juros de referência, setor externo e ciclo de negócios não afetam inadimplência; maior razão preços pagos por preços recebidos pela agricultura aumenta inadimplência; os processos políticos de renegociação da dívida rural induzem endividamento, risco moral e seleção adversa; e a relação inadimplência e determinantes retorna ao equilíbrio de longo prazo em 19 dias.

We identify the determinants of default rate in the National Rural Credit System of Brazil using the ARDL bounds testing approach for cointegration by Pesaran et al. (2001), and Granger causality tests by Toda \& Yamamoto (1995). The results showed that the reference interested rate, foreign sector and business cycles do not affect default rate, higher prices paid per prices received by the agricultural sector increases default rate, political processes of rural debt renegotiation induce higher debt levels, moral hazard and adverse selection, and the relation default rate and its determinants returns to long run equilibrium within 19 days.

${ }^{*}$ Economista pela UnB e mestrando na EPGE/FGV. Email: lucas . braga.melo@gmail . com

${ }^{\dagger}$ Departamento de Economia, Universidade de Brasília (UnB). Campus Darcy Ribeiro, Prédio da FACE, Asa Norte, Brasília, DF, Brasil. CEP 70910-900. Email: moisesresende@unb.br 


\section{INTRODUÇÃO}

Os diversos instrumentos de política agrícola disponíveis à formulação e execução da política agrícola no Brasil são classificados em crédito rural, zoneamento agrícola, seguro rural, instrumentos de comercialização e instrumentos de programas especiais de fomento setorial. Dentre estes, o crédito rural tem sido o instrumento tradicionalmente utilizado pelo governo brasileiro para subsidiar, financiar e/ou promover o setor agrícola.

O Sistema Nacional de Crédito Rural (SNCR) foi institucionalizado no Brasil pela Lei 4829 de cinco de novembro de 1965 e constituído pelo Banco Central do Brasil, Banco do Brasil S/A, que é o principal agente financeiro de crédito rural do país, Banco da Amazônia S/A e Banco do Nordeste S/A. Os órgãos vinculados ao SNCR são o Banco Nacional de Desenvolvimento Econômico e Social (BNDES), bancos privados e estaduais, caixas econômicas, cooperativas de crédito rural e sociedades de crédito, financiamento e investimentos; e como instituições articuladas os órgãos oficiais de valorização regional e de prestação de assistência técnica (Martins, 2010).

A política agrícola brasileira, no que diz respeito à concessão de crédito rural, tem se caracterizado pela forte interferência estatal, a qual estabelece a exigibilidade da aplicação dos recursos das reservas bancárias e tetos, quotas e taxas de juros praticadas no crédito rural (Araújo, 2011). As normas de aplicação dos recursos do crédito rural são aprovadas pelo Conselho Monetário Nacional (CMN) e publicadas pelo Banco Central do Brasil (BC) no Manual de Crédito Rural (MCR).

Em 2011, dos recursos destinados ao crédito rural no Brasil, 28,5\% foram recursos obrigatórios, a poupança rural e fundos constitucionais contribuíram com cerca de $20 \%$ cada um, o BNDES contribuiu com $24,5 \%$ e os $7 \%$ restantes dos recursos foram provenientes de formas alternativas de financiamento (Belik, 2014). Entre 2012 e 2014, cerca de 60\% dos saldos da carteira de crédito rural vieram de recursos de aplicações em que a taxa de juros era regulada pelo governo, sendo que mais de $50 \%$ dos saldos dessas aplicações estão sobre controle do setor público (BCB, 2014b). Apesar da crescente participação dos bancos privados na captação de recursos na forma de títulos específicos para o agronegócio via Letra de Crédito do Agronegócio (LCA), títulos pós-fixados como os Certificados de Recebíveis do Agronegócio (CDCAs), a participação destes ainda é pequena (Belik, 2014). De fato, ainda é o setor público quem arca com a maior parte dos recursos do crédito rural no Brasil.

Para manter a capacidade de financiamento do crédito rural, Távora $(2014$, p.38) menciona que o Governo Federal opera um modelo de financiamento com taxa de juros fixas e moderadamente baixas, estabelecidas previamente a cada safra; com a possibilidade de refinanciamento, em caso de incapacidade de pagamento dos tomadores de recursos; preferencialmente sem alocar diretamente recursos para fazer frente aos financiamentos rurais; e utilizando vários programas, muitos do quais com recursos provenientes do BNDES e títulos de crédito como os definidos na Lei 11076, de 30/12/2004, alterada pela Lei 11524 de 2007.

Relacionada à capacidade de financiamento do crédito rural está a questão das recorrentes renegociações e refinanciamentos da dívida rural pelo Governo Federal. Diversas vezes o governo opta por renegociar os financiamentos do SNCR no intuito de viabilizar a permanência de agricultores no limite da insolvência ou já insolventes na atividade agrícola. Agindo assim, o governo, cria incentivos ao aumento da proporção de tomadores mais propensos ao risco (efeito seleção adversa), à realização de investimentos de maior risco e mesmo ao não pagamento intencional dos empréstimos (efeito risco moral), uma vez que os agentes passam a incorporar a possibilidade de renegociação das dívidas em suas decisões (Stiglitz \& Weiss, 1981, 1983).

Elevadas taxas de descumprimento dos contratos de crédito rural reduzem a capacidade de financiar o SNCR e a eficiência no uso dos recursos pelos produtores, além de gerarem prejuízos ao sistema financeiro nacional e aos cofres públicos. Por exemplo, Távora (2014) estima um custo de $0,29 \%$ do PIB $^{1}$

\footnotetext{
${ }^{1}$ Tomando o Produto Interno Bruto (PIB) de R\$1,48 trilhão em preços de 2002.
} 
na equalização da taxa de juros do Programa Especial de Saneamento de Ativos (PESA) iniciado em 1998 e um custo de oportunidade do estoque da dívida pública e taxa Selic de $1,64 \%$ do PIB, ${ }^{2}$ decorrente do primeiro processo de securitização da dívida rural iniciado em 1965.

O objetivo do presente artigo é detectar os determinantes da inadimplência, modelando, estimando, testando e controlando econometricamente os efeitos do risco sistêmico, que é aquele decorrente do próprio ciclo de negócios da economia, do nível de endividamento dos produtores e de medidas tomadas pelo governo na condução da política de crédito rural sobre a inadimplência do crédito rural. Tal entendimento é de fundamental importância para formuladores da política de crédito rural, reguladores do sistema financeiro nacional e para tomadores de decisão das instituições financeiras do SNCR.

O presente artigo compreende essa introdução e mais cinco seções. A seção 2 faz a caracterização da política de crédito rural e renegociações da dívida rural no Brasil, além de elencar as potenciais falhas dessa política. A seção 3 apresenta a revisão da literatura sobre os fatores determinantes da inadimplência, a fundamentação teórica destes, em especial, os fatores geradores de risco sistêmico, faz uma revisão da literatura sobre as metodologias utilizadas na especificação e estimação de modelos de séries de tempo e formaliza o modelo econométrico utilizado. A seção 4 descreve os dados e a construção das variáveis do modelo econométrico base. A seção 5 estabelece o procedimento ARDL Teste de Limites para cointegração de Pesaran et al. (2001), os demais procedimentos econométricos e discute os resultados. Finalmente, a seção 6 apresenta as conclusões do trabalho.

\section{A POLÍTICA DE CRÉDITO RURAL NO BRASIL}

Nesta seção, fazemos a contextualização da política de crédito rural no Brasil, o histórico das renegociações da dívida rural, uma discussão das potenciais falhas e desafios da política de crédito rural no Brasil com vistas a levantarmos hipóteses passíveis de serem empiricamente testadas.

\subsection{Renegociação da Dívida Rural}

Em meados da década de 1990, em um cenário de declínio na rentabilidade do setor agrícola, há uma forte diminuição na oferta de crédito rural e, com isso, na receita inflacionária dos mutuários. Provavelmente, devido à conjunção desses fatores, à época, houve um elevado crescimento da taxa de inadimplência do crédito rural, em julho de 1994, a taxa de inadimplência era de 22,92\%, saltou para 38,76\% em dezembro de 1995 e para quase 55\% em setembro de 1997 (Arraes \& Teles, 1999).

Os altos níveis de endividamento e redução dos recursos para o refinanciamento do crédito rural reduziram a liquidez do setor agrícola, culminando na incapacidade generalizada do setor de honrar a enorme dívida. Assim, desde o início do Plano Real em 1994, o Governo Federal vem renegociando a divida rural em uma atuação ativa e quase anual, por meio da edição de medidas provisórias (MPV) enviadas à apreciação do legislativo (Távora, 2014). Em linhas gerais, vem ocorrendo sistematicamente, desde 1995, repactuações da dívida rural, as quais consistem no alongamento do prazo do financiamento, equalização da taxa de juros e cobrimento das garantias pela União. A Tabela -1 em apêndice apresenta todas as leis e normas que apreciaram negociações de dívidas dos produtores rurais desde 1995.

Focamos a seguir a primeira securitização da dívida rural e o Programa Especial de Saneamento de Ativos (PESA), que foram os maiores processos de renegociação até hoje, apesar de existirem ainda em andamento várias renegociações, passado por várias rodadas de modificações.

O primeiro processo de securitização da dívida rural ocorreu em três rodadas de renegociação e resultou nas Leis 9.138/1995, 9.866/1999 e 10.437/2002. Ao final desse processo, as condições de empréstimo estavam demasiadamente fáceis: 30 anos de prazo (de 1995 a 2025) para o pagamento da dívida, sem correção monetária e a uma taxa de juros de $3 \%$ ao ano, com desconto de 15 a $30 \%$ em algumas

${ }^{2}$ Idem. 
parcelas (bônus de adimplência) e a possibilidade de liquidação antecipada da dívida com desconto de 10 a $20 \%$ (Távora, 2014).

Já o PESA foi amparado pela Resolução nº 2.471 de 26 de fevereiro de 1998 do Conselho Monetário Nacional (CMN) e estabelecia que fossem emitidos títulos pelo Tesouro Nacional passíveis de aquisição por produtores rurais que quisessem alongar suas dívidas. Esses títulos serviriam como garantia e no final do prazo teriam valor de face equivalente à dívida. A contratação dessa renegociação deveria ser feita até 31 de julho de 1998 e o reembolso dos títulos aconteceria em vinte anos contados a partir da data da renegociação (Silvestrini \& Lima, 2011). Távora (2014) estima que um mutuário que adquirisse um título do PESA nas condições estabelecidas estaria recebendo um desconto de $43,75 \%$ de sua dívida.

\subsection{Inadimplência e Renegociações da Dívida Rural}

As repactuações da dívida rural acabaram beneficiando um pequeno grupo de grandes produtores à custa dos contribuintes (custo disperso). De fato, a maioria dos produtores não foi beneficiada, apesar de no processo político, os pequenos agricultores terem contribuído com sua imagem social frágil para que o lobby político financiado pelos grandes produtores conseguisse mobilizar a forte bancada ruralista do Congresso Nacional (Távora, 2014). Nesse aspecto, as renegociações são calcadas em um processo político que não considera a real capacidade de pagamento dos devedores, tampouco na capacidade destes gerarem renda e desenvolvimento (Távora, 2014). Por exemplo, com a aprovação de determinada lei ou regulação, todos os mutuários contemplados podem alongar sua dívida em dez anos, com três de carência e à taxa de juros de $3 \%$ ao ano. Como essas condições são muito amplas e atingem um grande número de produtores rurais, não têm qualquer ligação com a real capacidade de pagamento de cada mutuário.

Arraes \& Teles (1999) e Távora (2014) argumentam que, apesar de flexibilizarem os contratos de crédito de forma a transferir renda aos produtores rurais e facilitar o pagamento da dívida rural, as renegociações sistemáticas e amplas podem criar incentivos adversos. Particularmente, podem aumentar a proporção de tomadores de crédito propensos ao risco (efeito de seleção adversa), induzir os tomadores a realizarem investimentos de mais alto risco do que os que realizariam e a fazer menos esforço do que fariam para quitar as dívidas (efeito risco moral), o que acaba por resultar na quitação de uma parcela menor do que aquela que seria quitada em situação normal, já que existe uma alta probabilidade de renegociação (Stiglitz \& Weiss, 1981).

Ademais, o incentivo à inadimplência intencional ainda é potencializado pelo fato de que se há redução da taxa de juros para os inadimplentes, os adimplentes não têm direito a repetição de indébito. Em outras palavras, não se pode utilizar da medida processual que se peticiona a devolução de um valor pago indevidamente (Távora, 2014). Por exemplo, pela Lei 12844 de 2013, os mutuários inadimplentes que optassem pelo refinanciamento de até $\mathrm{R} \$ 200$ mil da dívida, arcariam com uma taxa de juros de 3,5\% a.a., enquanto os adimplentes permaneceriam arcando com a taxa inicial de juros de 8,75\% a.a. (Távora, 2014). De fato, como as várias MPs que tratavam da renegociação da dívida rural propunham medidas favoráveis apenas aos inadimplentes sem qualquer alusão aos adimplentes, geraram assim um claro incentivo para que ninguém se torne adimplente e para que o processo de renegociações se torne cíclico. Assim, uma hipótese importante é a de que grande parte dos fatores causadores da inadimplência no crédito rural se deve a ineficácia das políticas de concessão de crédito rural de períodos anteriores (Arraes \& Teles, 1999). Em outras palavras, a renegociação das dívidas pode induzir a maior inadimplência no crédito rural, uma hipótese que será testada no presente trabalho.

Nesse contexto, percebe-se que o processo político envolvido nas renegociações é complexo. Devido as constantes alterações que uma mesma renegociação sofre ao longo do tempo, é difícil precisar exatamente quando esta acaba ou termina, ou mesmo quais mutuários param de receber os benefícios ou quando esses benefícios melhoram após a modificação da resolução ou lei. 


\section{FUNDAMENTAÇÃO TEÓRICA E MODELO ECONOMÉTRICO}

Essa seção objetiva criar base teórica para justificar as variáveis de um modelo econométrico que contemple os principais fatores causadores da inadimplência no crédito rural no Brasil, em especial, levando em conta as amplas e sistemáticas renegociações políticas da dívida.

\subsection{Inadimplência e seus Determinantes: Modelos Macrofundamentados de Dados de Painel}

Após a crise financeira de 2008, ressurge o interesse em se investigar os efeitos na inadimplência de crédito de fatores macroeconômicos de risco sistêmico (Bonfim, 2009), que é aquele gerado sistematicamente pelas flutuações da economia ou por choques no sistema financeiro. Em linhas gerais, o risco sistêmico é gerado em períodos expansivos do ciclo de negócios quando os tomadores de crédito estão propensos e em condições de contrair empréstimos e as instituições financeiras credoras, propensas e em condições de assumir maiores risco. A realização do risco sistêmico tende a ocorrer nos períodos recessivos do ciclo de negócios quando a propensão e recursos para financiamento diminuem, o que leva à restrição de crédito, e a propensão e capacidade de pagamento dos mutuários se deteriora, o que leva ao aumento nos níveis de inadimplência (Jiménez \& Saurina, 2006). Com isso, há uma distância temporal entre a criação e a realização do risco sistêmico.

Bonfim (2009) classifica em três grupos os estudos que investigam os efeitos de fatores macroeconômicos de risco sistêmico na inadimplência ou risco de crédito: estudos que usam modelos com microdados dos mutuários quanto a índices contábeis e características intrínsecas; estudos que usam modelos que combinam informações do sistema financeiro e microdados dos empréstimos/contratos; e estudos que usam modelos de séries de tempo incluindo variáveis macroeconômicas e fatores de risco sistêmico ou modelos macroeconométricos. O presente trabalho se insere no terceiro grupo de estudos.

Fazemos a seguir uma revisão dos trabalhos de Ali \& Daly (2010), Bonfim (2009), Louzis, Vouldis \& Metaxas (2012) e Koopman, Kräussl, Lucas \& Monteiro (2009), os quais investigam os efeitos na inadimplência ou risco de crédito de fatores macroeconômicos de risco sistêmico e fatores de risco idiossincrático, que é o decorrente das características dos mutuários e das condições de empréstimos. 0 nosso objetivo com isso é dar suporte à especificação do nosso modelo econométrico.

Ali \& Daly (2010) empregam um modelo macroeconométrico em que a inadimplência agregada pode ser explicada pelas variáveis macroeconômicas de risco sistêmico: taxa de juros, taxa de crescimento do PIB e nível de endividamento defasado da economia. Os resultados mostraram que a inadimplência agregada é afetada positivamente pelo nível de endividamento defasado e negativamente pelo PIB, sendo mais sensível a variações no PIB nos EUA do que na Austrália.

Bonfim (2009) investiga se o risco de crédito pode ser explicado por variáveis macroeconômicas de risco sistêmico e também por variáveis de risco idiossincrático. As estimações com dados de 3.000 empresas portuguesas mostram que a condição financeira das empresas mutuarias é fundamental para explicar a inadimplência. Já utilizando dados de painel com variáveis em nível mais agregado, os autores observam que fatores macroeconômicos têm efeitos significativos na inadimplência. Assim, concluem que resultados mais robustos serão obtidos se forem incluídas variáveis de risco idiossincrático e macroeconômicas de risco sistêmico (Bonfim, 2009).

Na mesma linha, Louzis et al. (2012) investigam os efeitos dos riscos idiossincrático e sistêmico no sistema financeiro grego, considerando a taxa de inadimplência de vários tipos de empréstimos e variáveis explicativas similares às usadas por Ali \& Daly (2010) e Bonfim (2009), adicionando mais variáveis macroeconômicas de risco sistêmico (nível de endividamento do governo, taxa de desemprego e inadimplência defasada) e variáveis de risco idiossincrático do setor bancário e de características dos empréstimos. A inclusão da variável nível de endividamento do governo no modelo incorpora a ideia de que um aumento no nível de endividamento deste deteriora a liquidez do sistema financeiro, o que 
leva os bancos a restringirem a oferta de crédito na busca por maior liquidez, inviabilizando assim a rolagem de dívidas e aumentando a inadimplência. A inclusão da taxa de desemprego justifica-se por esta ser uma variável proxy da renda disponível e, por isso, deve apresentar um efeito positivo na taxa de inadimplência. Por fim, a inclusão da variável dependente (taxa de inadimplência) defasada no modelo incorpora a ideia de que após sofrerem com elevados níveis de inadimplência, os bancos se tornam mais cautelosos ao concederem empréstimos, o que diminui a taxa de inadimplência futura.

Louzis et al. (2012) ainda observam que os efeitos na taxa de inadimplência das variáveis macroeconômicas de risco sistêmico parece variar de acordo com o tipo de empréstimo. Por exemplo, a inadimplência no financiamento de empresas é mais sensível ao risco sistêmico mensurado pelas variações na taxa de crescimento do PIB, enquanto no caso do crédito ao consumidor, a taxa de desemprego e o nível de endividamento da economia são mais importantes. Em suma, os fatores de risco sistêmico influenciam de maneira diferente os diferentes setores da economia.

\subsection{Inadimplência e seus Determinantes: Modelos Macrofundamentados de Séries de Tempo}

Utilizamos como base para a especificação do nosso modelo econométrico o estudo de Bofondi \& Ropele (2011) que estimam dois modelos uniequacionais de séries de tempo para o risco do crédito das empresas e risco de crédito das famílias italianas, adotando, porém, estratégias de estimações diferentes, de forma a controlar possíveis problemas de endogeneidade. Os autores possibilitam que variáveis macroeconômicas possam influenciar de maneiras diferentes o risco de crédito das firmas e das famílias. De toda forma, utilizam em ambos os modelos a variável dependente Novos Empréstimos Ruins (NER), obtida como a razão entre os novos empréstimos de alto risco e o estoque de empréstimos em situação regular ou de risco normal para firmas e famílias e variáveis explicativas dos seis grupos:

(i) grupo das relacionadas ao estado geral da economia;

(ii) grupo das relacionadas às condições de estabilidade dos preços;

(iii) grupo das relacionadas ao custo do serviço da dívida;

(iv) grupo das relacionadas ao nível de endividamento;

(v) grupo das relacionadas à riqueza no mercado de capitais e no mercado financeiro; e

(vi) grupo das relacionadas ao crescimento econômico.

Finalmente, por considerarem que choques macroeconômicos levam tempo até começarem a afetar (piorar ou melhorar) a capacidade de pagamento dos mutuários, também incluem defasagens das variáveis macroeconômicas no modelo econométrico:

$$
N E R_{t}=c+\sum_{j=1}^{q} \beta_{j} N E R_{t-j}+\sum_{j=0}^{p_{i}} \gamma_{j} X_{i, t-j}+\varepsilon_{t},
$$

em que a variável dependente Novos Empréstimos Ruins $(N E R)$ é regredida nela mesma defasada de ordem 1 a $q$ (componentes autoregressivos), no vetor de variáveis macroeconômicas $X_{i}, i=1, \ldots, I$, defasadas de ordem 0 a $p_{i}$ e em uma constante $c$. A estrutura de defasagens $q$, $p_{i}$, com $i=1, \ldots, I$ é definida com base na significância estatística dos coeficientes e critérios de informação de Akaike (AIC) e Schwarz (SIC).

Bofondi \& Ropele (2011) estimam a equação (1) por Mínimos Quadrados Ordinários (MQO) com erros padrão robustos de Newey-West e observam que NER das famílias e NER das empresas são explicadas por apenas algumas variáveis, quais sejam: as condições econômicas gerais, o custo dos empréstimos e o nível de endividamento.

Gambera (2000) apresenta técnicas econométricas que podem ser utilizadas com séries temporais para prever as condições financeiras de bancos e de carteiras de crédito com base nos ciclos macroeconômicos. $\mathrm{O}$ autor estima um modelo Auto Regressivo de Defasagens Distribuídas (ARDL) similar ao 
de Bofondi \& Ropele (2011) e, também, um Vetor Auto Regressivo (VAR) para prever e explicar a taxa de inadimplência. Ademais, o autor realiza testes de estresses para averiguar o comportamento do risco de crédito em situações adversas do ciclo de negócios.

No que se referem às variáveis dependentes, os tipos de empréstimos analisados por Gambera (2000) são divididos em três setores: agrícola, comercial-industrial e habitacional. Dentro de cada um desses setores, duas categorias de empréstimos problemáticos são consideradas: a categoria chamada de inadimplência, a qual é composta pelo total dos empréstimos com 30 a 89 dias de atraso dividido pelo total de empréstimos; a segunda categoria chamada de crédito vencido, definida como o saldo dos empréstimos com 90 ou mais dias de atraso também dividido pelo total de empréstimos. Variáveis macroeconômicas como a taxa de desemprego, a produção da agropecuária, o índice de confiança do consumidor e o número de falências de empresas são significativas e aparentam ter uma relação robusta com a taxa de inadimplência.

Por fim, destacamos o modelo empírico de Arraes \& Teles (1999). Com o objetivo de explicar a inadimplência do crédito rural no Brasil e na região Nordeste durante os anos 90 , os autores partem de uma série de hipóteses: o governo brasileiro intervém fortemente no mercado de crédito rural controlando o volume de saldos disponíveis e a taxa de juros aplicada ao crédito; o processo de renegociação da dívida rural, que vem ocorrendo no Brasil, caracteriza uma transferência de renda aos mutuários, facilitando o cumprimento das obrigações contratuais direta e indiretamente; o volume das novas importações agrícolas, fruto da recente abertura comercial da economia à época, competem com os produtores domésticos e influem negativamente na rentabilidade do setor, e, consequentemente, em sua adimplência; e os autores acreditam que após o Plano Real, a agricultura muda de um tipo rent seeking para um tipo profit seeking, decorrente das mudanças estruturais da política de crédito rural e da estabilização macroeconômica.

Arraes \& Teles (1999) desenvolvem dois modelos econométricos para testar suas hipóteses sobre a inadimplência de crédito rural agregada no Brasil. o primeiro é uma regressão de uma única equação linear e o segundo é um sistema de equações simultâneas. Em linhas gerais, há alguns resultados interessantes. Nota-se que a partir das mudanças estruturais da política de crédito rural no Plano Real, o risco de crédito passou a ser mais explicado pela rentabilidade do setor e pela taxa de juros cobrada ao produtor rural. Tal fato corrobora a argumentação de que o setor rural passara de um tipo rent seeking para profit seeking como consequência da redução do crédito rural subsidiado e menor facilidade de renegociação da dívida. Ademais, nota-se que a quantidade produzida e as importações do setor rural estão relacionadas ao grau de inadimplência.

Em suma, há uma vasta gama de artigos publicados principalmente pelos Bancos Centrais de vários países, incluindo o Bank of International Settlement (BIS) e aqueles integrantes do Eurosistema que explicam o risco de crédito por meio de séries temporais de ciclos de negócios. No entanto, tais trabalhos estão preocupados com a previsão da variável dependente, portanto, em geral, não se preocupam em adotar estratégias de estimações que trate dos problemas de endogeneidade das variáveis independentes. Além disso, realizam inferências não abrangem a literatura corrente de microfinanças.

Particularmente para o Brasil, Arraes \& Teles (1999) utilizaram um sistema de equações com objetivo bastante parecido ao nosso, diferenciando-se ao considerar os efeitos do Plano Real, juntamente com a mudança estrutural da política de crédito rural no país e tratar de características especifica do crédito rural. Cabe notar que ao estimar tal sistema, Arraes \& Teles (1999) tratam o problema de endogeneidade utilizando o MQ2E e variáveis instrumentais.

\subsection{Modelo Econométrico}

Com base no trabalho de Bofondi \& Ropele (2011), consideramos que inadimplência no SNCR, $y$, é determinada pelo endividamento do setor, pelos processos políticos de renegociação da dívida do SNCR, 
pela não rentabilidade do setor agrícola, pelo ciclo de negócios e pela rentabilidade e atratividade do setor externo, segundo a seguinte equação de cointegração:

$$
\begin{array}{r}
y_{t}=\beta_{0}+\beta_{1} \text { dummy }_{t}+\beta_{2} e n d_{t}+\beta_{3} e n d_{t}^{2}+\beta_{4} e n d_{t} \times d u m m y_{t}+\beta_{5} t j_{t}+\beta_{6} p_{t}+\beta_{7} i a e_{t}+\beta_{8} i c_{t} \\
+\beta_{9} \Delta \% p i b_{t}+\beta_{10} \delta s_{t}+u_{t},
\end{array}
$$

em que $\beta_{0}, \ldots, \beta_{10}$ são parâmetros de longo prazo; o subscrito $t$ denota tempo; $y$ é a variável inadimplência no SNCR; dummy é uma variável dicotômica gerada a partir da análise dos processos de renegociação da dívida rural descritos por Távora (2014) e Silvestrini \& Lima (2011) e que será explicada na seção 4.2 deste artigo; end e $e n d^{2}$ são nível e nível ao quadrado de endividamento no SNCR; end $\times$ dummy é uma variável de interação endividamento vezes dummy; $t j$ é a taxa referencial de juros mensal da economia brasileira; $p$ é uma medida da não rentabilidade relativa do setor rural; $\Delta \% s$ é a taxa de variação dos saldos de créditos destinados ao SNCR; iae é o índice de atratividade ou rentabilidade das exportações agrícolas; ic é a média mensal ponderada dos preços de commodities agropecuárias exportadas produzidas no Brasil; $\Delta \%$ pib é a taxa de crescimento do PIB real; e $u$ é o termo de erro aleatório do modelo.

O modelo econométrico da equação (2) é, muito provavelmente, isento de problemas de endogeneidade devido a variáveis relegadas ao erro que também afetam variáveis explicativas do modelo. As variáveis que determinam $t j$ e também inadimplência estão relacionadas à oferta e demanda de crédito rural, as quais já estão incluídas explicitamente no modelo e não relegadas ao erro. Por exemplo, variações na oferta de crédito rural são plenamente captadas pela taxa de crescimento real dos saldos de crédito, $\Delta \% s$; variações na demanda por crédito são captadas plenamente pela variável não rentabilidade do setor rural, $p$, pelas variáveis relacionadas à atratividade do mercado externo para a agricultura brasileira, iae e ic, e pela variável macroeconômica do ciclo de negócios da economia nacional, crescimento real do PIB, $\Delta \% p i b$. Finalmente, a inclusão no modelo da variável dummy para as renegociações políticas da dívida rural controla para o fato de que o endividamento, taxa de juros e, obviamente, inadimplência podem ser afetadas por renegociações da dívida. Sendo assim, o modelo como está formulado elimina por completo a possibilidade de endogeneidade do endividamento, além de contribuir para diminuir qualquer suspeita de endogeneidade da taxa de juros. Nesse ponto, ainda se poderia suspeitar de causalidade reversa no modelo, pois taxa de juros afeta inadimplência e inadimplência pode afetar taxa de juros. Para dirimir tal dúvida, efetuamos testes de causalidade de Granger, os quais fornecem fortes indícios de que, no caso do crédito rural no Brasil, a taxa de juros Granger causa inadimplência.

\section{DADOS, CONSTRUÇÃO E DESCRIÇÃO DAS VARIÁVEIS E SEUS EFEITOS ESPERADOS}

Nessa seção fazemos a descrição pormenorizada das variáveis do modelo e os procedimentos adotados na construção destas.

\subsection{Inadimplência no SNCR, $y$}

O Basel Committee on Banking Supervision (BCBS, 2005) define que há inadimplência quando o banco considera improvável que o devedor cumpra o contrato sem ter de recorrer aos colaterais do contrato; e/ou quando o mutuário está a mais de 90 dias em atraso com alguma obrigação. Seguindo estas linhas do Comitê de Basiléia, o Banco Central do Brasil (BCB) classifica os saldos das operações de crédito no Brasil em nove níveis em ordem crescente de risco, quais sejam: AA (o de menor nível de risco), A, B, C, D, E, F, G e H (o de mais alto nível de risco). Como os saldos de operações de crédito com atrasos superiores a noventa dias se enquadram, no máximo, na classe $E$ (BCB, 2000) e de acordo com as definição das séries de tempo disponibilizada pelo Banco central do Brasil (BCB, 2014a), a taxa de inadimplência agregada do setor rural é a soma dos saldos das operações de crédito do setor rural de risco de níveis de $\mathrm{E}$ a $\mathrm{H}$. 
Utilizamos como variável dependente na equação (2) dos nossos modelos a série novos empréstimos ruins, $y$, proposta por Bofondi \& Ropele (2011) e calculada como a razão fluxo de novos empréstimos de alto risco sobre o estoque de empréstimos em situação regular ou de risco normal, segundo a seguinte equação:

$$
y_{t}=\frac{A-B}{C},
$$

onde $A=$ saldo das operações de crédito do setor rural de risco de nível E, F, G e $\mathrm{H}$ em $t$;

$B=$ saldo das operações de crédito do setor rural de risco de nível $\mathrm{E}, \mathrm{F}, \mathrm{G}, \mathrm{H}$ em $t-1$;

$C=$ saldo das operações de crédito do setor rural de risco de nível AA, A, B e C em $t-1$.

\subsection{Variável Política Relacionada às Renegociações da Dívida Rural, dummy, Nível e Quadrado do Nível de Endividamento dos Produtores Rurais e Variável de Interação, end, end $^{2}$ e end $\times$ dummy}

Para mensurar e controlar para os efeitos das repactuações da dívida rural na inadimplência, criouse uma variável dummy com base nos processos de renegociação descritos por Távora (2014) e Silvestrini \& Lima (2011), sumarizados na Tabela -1 do Apêndice. Assim, a variável dicotômica dummy recebe o valor um nos quatro meses subsequentes a publicação de uma lei/regulação que repactua a dívida rural ou modifica uma lei já publicada e zero nos demais períodos. A Figura 1 relaciona as Leis e Normas sobre renegociação da dívida rural e suas datas.

O nível de endividamento do SNCR, end, corresponde à porcentagem dos saldos totais do crédito rural em relação ao PIB acumulado em doze meses a preços correntes da economia brasileira, uma série disponibilizada pelo BCB (2014a).

Quando há acúmulo de dívidas em relação aos ativos, a capacidade de pagamento dos empréstimos diminui (Ali \& Daly, 2010), o que deve aumentar a inadimplência. No entanto, pode ser que a partir de certo nível de endividamento, credores tenham que renegociar dívidas, o que pode alterar o efeito do nível da dívida na inadimplência. Ademais, o efeito do endividamento na inadimplência pode ser contaminado pelo efeito risco moral (Bofondi \& Ropele, 2011), tal que quanto maior é o nível de endividamento, maior é a pressão para renegociar a dívida. Assim, os tomadores de crédito podem optar por operar em níveis de endividamento maiores do que aqueles que operariam em condições normais de modo a induzir renegociações (efeito risco moral do nível de endividamento). Por isso, a especificação do modelo que utilizamos permite que o efeito do endividamento na inadimplência possa variar com o

Figura 1. Meses em que a variável dummy recebe 0 valor um e as leis/regulamentações associadas.

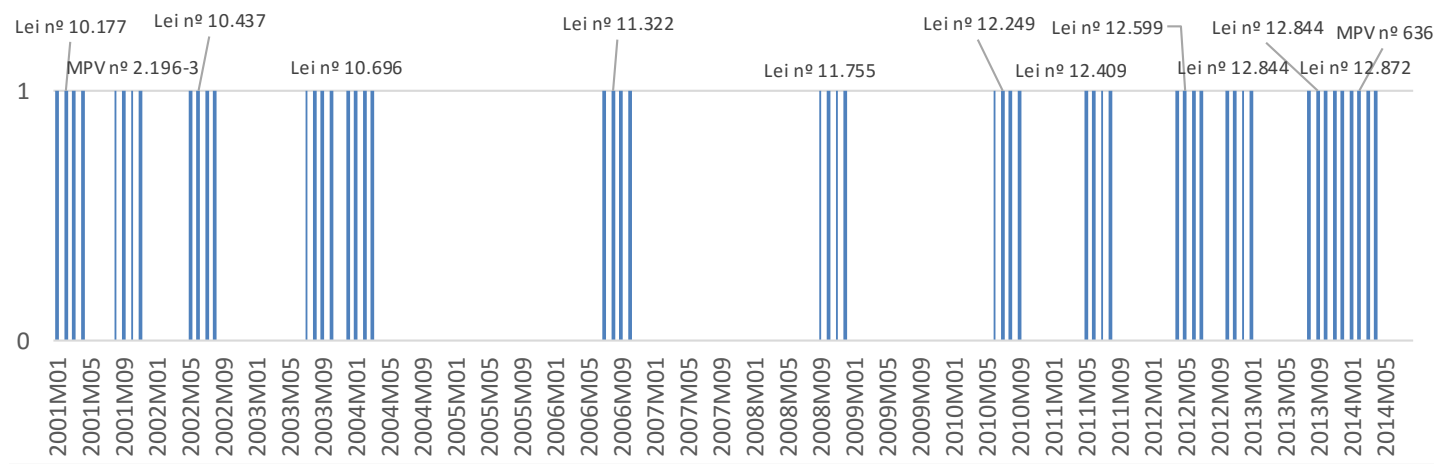


próprio nível de endividamento e com a própria renegociação da dívida, tal que segundo a equação (2) o efeito do endividamento na inadimplência é dado pela seguinte equação:

$$
\frac{\partial y}{\partial e n d}=\beta_{2}+2 \beta_{3} \text { end }+\beta_{4} d u m m y,
$$

em que se espera que o efeito direto do endividamento na inadimplência, $\beta_{2}+2 \beta_{3}$ end, seja positivo, pois o endividamento deve reduzir a capacidade de pagamento dos devedores. 0 efeito indireto do endividamento na inadimplência, $\frac{\partial^{2} y}{\partial \text { end } \partial \text { dummy }}=\beta_{4}$, se dá via renegociação, tal que se for negativo é porque a renegociação fez com que o maior endividamento diminuísse inadimplência (efeito risco moral). Em suma, o efeito do endividamento na inadimplência é uma questão a ser investigada empiricamente, pois dependerá de qual efeito é preponderante: redução da capacidade de pagamento ou risco moral.

A especificação do modelo que utilizamos também permite que o efeito da renegociação seja função do nível de endividamento no SNCR, tal que pela equação (2) esse efeito é dado pela seguinte equação:

$$
\frac{\partial y}{\partial d u m m y}=\beta_{1}+\beta_{4} \text { end }
$$

tal que, como os processos políticos envolvidos nas renegociações das dívidas acabam por facilitar o pagamento da dívida rural, um sinal negativo de $\partial y / \partial d u m m y$ indica diminuição na inadimplência porque a melhora na capacidade de pagamento suplanta o efeito risco moral/seleção adversa de Stiglitz \& Weiss (1981, 1983), ao passo que um sinal positivo, indica que o efeito risco moral/seleção adversa de Stiglitz e Weiss suplanta a melhora na capacidade de pagamento dos mutuários do SNCR.

\subsection{A Não Rentabilidade do Setor Rural, $p$}

Arraes \& Teles (1999) observaram que a baixa rentabilidade relativa do setor rural, $p$, explica parte da inadimplência no crédito rural, pois quanto menos rentável é a atividade, menor é a capacidade do tomador de recursos de pagar a dívida e, portanto, maior a taxa de inadimplência. Como Arraes \& Teles, utilizamos como proxy da não rentabilidade do setor rural a variável

$$
p_{t}=\frac{i p p_{t}}{i p r_{t}}
$$

em que $i p p_{t}$ é a série do índice de preços pagos pelos produtores rurais em $t$ e $i p r_{t}$ é a série do índice de preços recebidos pelos produtores rurais no tempo $t$, ambos obtidos com séries de mesmo nome do Instituto Brasileiro de Economia (FGV-IBRE, 2014).

Esperamos que o efeito de $p$ na inadimplência seja positivo, ou seja, aumentos na não rentabilidade do setor devem aumentar a inadimplência no SNCR, pois implicam menor capacidade de pagamento dos tomadores de recursos.

\subsection{Variáveis Relacionadas à Rentabilidade das Exportações Agrícolas, iae e ic}

Como parte importante do setor agropecuário brasileiro é voltada às exportações, utilizamos a variável índice de atratividade das exportações agrícolas, iae, que capta a rentabilidade do setor relacionada ao ciclo internacional de negócios. A série $i a e_{t}$ é disponibilizada pelo Centro de Estudos Avançados em Economia Aplicada (Cepea), ${ }^{3}$ e considera em seu cálculo a taxa de câmbio efetiva do setor agrícola, o volume de exportações e o preço das commodities agrícolas, o que deve capturar a atratividade do

\footnotetext{
${ }^{3}$ http://www. cepea.esalq.usp.br/br
} 
setor agrícola exportador. Outra variável de controle que utilizamos é o $i c_{t}$ que é o IC-Br Agropecuária, uma média mensal ponderada dos preços de commodities agropecuárias exportadas produzidas no Brasil disponibilizada pelo Banco Central do Brasil (BCB, 2014a).

Esperamos um efeito negativo de cada uma dessas variáveis na inadimplência, pois o aumento da atratividade/rentabilidade externa das commodities agrícolas deve aumentar a capacidade de pagamento dos tomadores de recursos do sistema de crédito rural.

\subsection{Variáveis Macroeconômica do Ciclo de Negócios da Economia Nacional, $\Delta \% p i b$ e $\Delta \% s$}

A relação entre o ciclo de negócios, a oferta de crédito e a taxa de inadimplência tem sido mensurada pela taxa de variação do PIB da economia (Simons \& Rolwes, 2009) e pela taxa de crescimento real dos saldos de crédito (Jiménez \& Saurina, 2006). Com base nesses trabalhos, utilizamos a taxa mensal de crescimento do PIB real, $\Delta \% p i b$, e a taxa mensal de crescimento dos saldos de créditos destinados ao setor agropecuário, $\Delta \% s$, ambas disponibilizadas pelo BCB (2014a).

Espera-se que a inadimplência no SNCR seja negativamente afetada por $\Delta p i b$, mas o efeito de $\Delta s$ é ambíguo, pois o aumento da oferta de crédito pode desafogar os tomadores de crédito (efeito negativo na inadimplência), mas também pode sinalizar aos tomadores de recursos leniência dos credores (efeito positivo na inadimplência).

\subsection{Custo da Dívida, $t j$}

Bofondi \& Ropele (2011), Ali \& Daly (2010), e Koopman et al. (2009) argumentam que a taxa de juros é positivamente relacionada ao não comprimento das obrigações de crédito. A ideia é que quanto maior for o custo da dívida, mais difícil será pagá-la ou refinanciá-la. Bofondi \& Ropele (2011) utilizam a EURIBOR a três meses como proxy da taxa de juros cobrada às famílias italianas e Jiménez \& Saurina (2006) utilizam a taxa de juros interbancário do sistema financeiro espanhol. No presente artigo, utilizamos a taxa referencial de juros mensal da economia brasileira, como Arraes \& Teles (1999). A série $t j_{t}$ foi obtida no Ipeadata (IPEA, 2014) e esperamos um sinal positivo o coeficiente de $t j$.

\section{ESTRATÉGIA DE ESTIMAÇÃO E DISCUSSAO DOS RESULTADOS}

O presente estudo examina a relação entre a inadimplência, renegociações políticas da dívida rua e questões de risco moral/seleção adversa no período de janeiro de 2001 a agosto de 2014 no Brasil. Para tanto, utiliza nove séries de tempo para as variáveis do modelo econométrico de longo prazo formalizado com a equação (2). A Tabela 1 apresenta as estatísticas descritivas das séries de tempo dessa variáveis.

Tabela 1. Estatísticas descritivas das séries.

\begin{tabular}{lcccccccccc}
\hline & $y t$ & end & end & $t j$ & $\Delta \% s$ & $p$ & iae & ic & $\Delta \% p i b$ & end $\times$ dummy \\
\hline Média & 0,044 & 3,160 & 10,379 & 0,138 & 0,723 & 1,179 & 101,058 & 113,201 & 0,311 & 1,508 \\
Mediana & 0,034 & 3,265 & 10,660 & 0,115 & 0,777 & 1,223 & 99,425 & 108,870 & 0,268 & 0,000 \\
Máximo & 1,681 & 4,820 & 23,232 & 0,547 & 6,756 & 1,487 & 132,840 & 166,870 & 8,409 & 4,790 \\
Mínimo & $-4,133$ & 1,930 & 3,725 & 0,000 & $-18,178$ & 0,793 & 83,870 & 63,700 & $-10,560$ & 0,000 \\
Desvio-padrão & 0,489 & 0,630 & 4,138 & 0,113 & 2,162 & 0,170 & 9,912 & 23,775 & 3,731 & 1,693 \\
Número de observações & 164 & 164 & 164 & 164 & 164 & 164 & 164 & 164 & 164 & 164 \\
\hline
\end{tabular}

Notas: A série $e n d^{2}$ denota o quadrado da série $e n d$; a série $e n d \times d u m m y$ é o resultado da multiplicação da série end pela série dummy. 
Há três hipóteses fundamentais a serem empiricamente testadas no presente trabalho. A primeira diz respeito ao efeito do endividamento, end, na inadimplência, que pode ser positivo, se a redução da capacidade de pagamento suplanta o efeito risco moral e negativo, se o efeito risco moral for preponderante. A segunda é sobre o efeito dos processos políticos de renegociações da dívida do SNCR na inadimplência. Se esse efeito for negativo, indicando diminuição na inadimplência, a melhora na capacidade de pagamento com a renegociação suplanta o efeito risco moral/seleção adversa de Stiglitz \& Weiss $(1981,1983)$, ao passo que se apresentar efeito positivo é porque o efeito risco moral/seleção adversa de Stiglitz e Weiss é preponderante. Por fim, a terceira hipótese é de que a inadimplência no crédito rural é afetada por variáveis de não rentabilidade do setor agrícola, variáveis macroeconômicas ligadas ao ciclo de negócios e a oferta de crédito rural e por variáveis de rentabilidade e atratividade do setor externo.

Para testar tais hipóteses, estimamos a equação de cointegração (2) seguindo o procedimento autoregressivo de defasagens distribuídas (ARDL) teste de limites (bounds tests) para cointegração desenvolvido por Pesaran \& Shin (1999) e Pesaran et al. (2001).

O procedimento ARDL teste de limites para cointegração (ARDL bounds testing) tem várias vantagens em relação a outras técnicas de cointegração como, o procedimento em dois estágios de Engle \& Granger (1987) e método de informação completa (full information) de Johansen \& Juselius (1990). Em primeiro lugar, o ARDL teste de limites pode ser aplicado independentemente de as variáveis serem integradas de ordem zero ou um ou uma combinação (Pesaran \& Shin, 1999). Em segundo lugar, o procedimento permite que se empregue um número suficiente de defasagens de modo a capturar o processo de geração de dados na metodologia do geral ao específico. Em terceiro lugar, o modelo de correção de erros (ECM) pode ser derivado do modelo ARDL por uma transformação linear simples, que integra ajustes de curto prazo com equilíbrio de longo prazo, sem perda de informações de longo prazo. Em quarto lugar, as propriedades em amostras pequenas do procedimento ARDL teste de limites são muito superiores às da técnica de cointegração de Johansen \& Juselius, 1990 (Pesaran \& Shin, 1999). Em quinto lugar, endogeneidade deixa de ser um problema no procedimento ARDL teste de limites, pois o procedimento é livre de correlação residual dos erros. De fato, como Pesaran \& Shin (1999) demonstram, se o número de defasagens do modelo ARDL for determinado corretamente, o procedimento é livre de correlação serial dos erros e, portanto, de endogeneidade. Em sexto lugar, o método ARDL teste de limites permite distinguir entre variáveis dependentes e explicativas (Jalil \& Feridun, 284-291).

O primeiro passo no procedimento ARDL teste de limites de Pesaran et al. (2001) consiste em se testar para raiz unitária nas séries de modo a verificar que nenhuma variável do modelo (2) é integrada de ordem dois ou de maior ordem. Isso porque o procedimento ARDL teste de limites pode ser aplicado somente se as variáveis forem $\mathrm{I}(0), \mathrm{I}(1)$ ou fracionadamente integradas, pois na presença de variáveis integradas de ordem dois, I(2), os valores críticos da estatística $F$ fornecidos por Pesaran et al. (2001) se tornam inválidos para inferência (Ouattara, 2004).

No presente estudo, utilizamos os testes de raiz unitária Dickey-Fuller Aumentado, ADF (Dickey \& Fuller, 1979), e Phillips-Perron ou PP (Phillips \& Perron, 1988), tal que se o $p$-valor do teste excede 5\%, não rejeitamos a hipótese nula de que a série possui uma raiz unitária e, portanto, é não estacionária. No caso de rejeição da hipótese nula, se o $p$-valor do teste de raiz unitária para a primeira diferença da série, $\Delta$ série $_{t}=$ série $_{t}-$ série $_{t-1}$, exceder $10 \%$ indicando que $\Delta$ série $_{t}$ é estacionária ou I(0), consideramos a série no nível integrada de ordem um ou, simplesmente, $\mathrm{I}(1)$. De toda forma, efetuamos os testes para a primeira diferença de todas as séries. A Tabela 2 apresenta os resultados dos testes.

Pelos resultados dos testes na Tabela 2 , as séries das variáveis $e n d$, $e n d^{2}, p$ e ic são não estacionárias no nível, mas são no nível, ou seja, são integradas de ordem 1, I(1). As demais séries são estacionárias no nível, ou seja, são integradas de ordem zero, I(0). Portanto, temos uma clara rejeição da hipótese de que há séries I(2), podemos seguir para o segundo passo do procedimento ARDL teste de limites de Pesaran et al. (2001). 
Tabela 2. Resultados dos testes de raiz unitária Dickey-Fuller Aumentado (ADF) e Phillips-Perron (PP).

\begin{tabular}{|c|c|c|c|c|c|c|c|}
\hline \multirow[b]{2}{*}{ Variável } & \multicolumn{3}{|c|}{ Teste ADF } & \multicolumn{3}{|c|}{ Teste PP } & \multirow[b]{2}{*}{ Conclusão } \\
\hline & $\begin{array}{l}\text { Termos } \\
\text { incluídos }\end{array}$ & $\begin{array}{c}\text { Número de } \\
\text { defasagens } \\
\text { selecionadas } \\
\text { pelo critério SIC }\end{array}$ & $p$-valor & $\begin{array}{c}\text { Termos } \\
\text { incluídos }\end{array}$ & $\begin{array}{l}\text { Bandwidth } \\
\text { usando } \\
\text { Bartlett } \\
\text { kernel }\end{array}$ & $p$-valor & \\
\hline$y$ & int & 1 & 0,000 & int & 5 & 0,000 & $\mathrm{I}(0)$ \\
\hline$\Delta y$ & nenhum & 11 & 0,000 & nenhum & 34 & 0,000 & $\mathrm{I}(0)$ \\
\hline dummy & int & 3 & 0,000 & int & 6 & 0,000 & $\mathrm{I}(0)$ \\
\hline$\Delta d u m m y$ & nenhum & 7 & 0,000 & nenhum & 16 & 0,000 & $\mathrm{I}(0)$ \\
\hline end & nenhum & 0,000 & 1 & nenhum & 5 & 0,000 & $\mathrm{I}(1)$ \\
\hline$\Delta e n d$ & int & 0 & 0,000 & int & 5 & 0,000 & $\mathrm{I}(0)$ \\
\hline$e n d^{2}$ & nenhum & 0 & 1,000 & nenhum & 6 & 1,000 & $\mathrm{I}(1)$ \\
\hline$\Delta e n d^{2}$ & nenhum & 5 & 0,027 & nenhum & 7 & 0,000 & $\mathrm{I}(0)$ \\
\hline end $\times$ dummy & int & 0 & 0,000 & int & 7 & 0,000 & $\mathrm{I}(0)$ \\
\hline$\Delta($ end $\times$ dummy $)$ & nenhum & 0 & 0,000 & nenhum & 19 & 0,000 & $\mathrm{I}(0)$ \\
\hline$t j$ & int, tend & 12 & 0,013 & int, tend & 5 & 0,000 & $\mathrm{I}(0)$ \\
\hline$\Delta t j$ & nenhum & 11 & 0,000 & nenhum & 1 & 0,000 & $\mathrm{I}(0)$ \\
\hline$p$ & int, tend & 1 & 0,763 & nenhum & 4 & 0,330 & $\mathrm{I}(1)$ \\
\hline$\Delta p$ & nenhum & 0 & 0,000 & nenhum & 4 & 0,000 & I(0) \\
\hline iae & int & 1 & 0,011 & int, tend & 4 & 0,011 & $\mathrm{I}(0)$ \\
\hline$\Delta i a e$ & nenhum & 12 & 0,000 & nenhum & 13 & 0,000 & $I(0)$ \\
\hline$i c$ & int, tend & 1 & 0,072 & int & 2 & 0,235 & $\mathrm{I}(1)$ \\
\hline$\Delta i c$ & nenhum & 0 & 0,000 & nenhum & 2 & 0,000 & $\mathrm{I}(0)$ \\
\hline$\Delta \% p i b$ & int & 11 & 0,015 & nenhum & 50 & 0,000 & $\mathrm{I}(0)$ \\
\hline$\Delta \Delta \% p i b$ & nenhum & 13 & 0,000 & nenhum & 22 & 0,000 & $\mathrm{I}(0)$ \\
\hline$\Delta \% s$ & int & 12 & 0,087 & int & 4 & 0,000 & $\mathrm{I}(0)$ \\
\hline$\Delta \Delta \% s$ & nenhum & 11 & 0,000 & nenhum & 31 & 0,000 & $\mathrm{I}(0)$ \\
\hline
\end{tabular}

Notas: int $=$ intercepto e tend $=$ variável tendência; int e tend são incluídas se a variável tendência é estatisticamente significante a 10\%, caso contrário, apenas int é incluída se significante a 10\%, caso contrário, nenhuma é incluída. 0 número de defasagens do teste ADF é determinado pelo Critério de Informação de Schwarz (SIC) e para o teste PP, por Newey-West bandwidth usando Bartlett kernel.

A análise de cointegração entre variáveis nada diz sobre o sentido da causalidade entre estas. Nesse sentido, um passo comum em estudos de cointegração é se aplicar testes de causalidade de Granger para se investigar sobre o sentido de causalidade das variáveis (Stern \& Enflo, 2013). De fato, diz-se que uma variável $x$ Granger causa outra variável $z$ se esta pode ser mais bem prevista se utilizarmos a história de $x$ e $z$ do que apenas a própria história de $z$. O conceito de causalidade de Granger se baseia na ideia de ordenação causal, segundo a qual duas variáveis podem ser contemporaneamente correlacionadas por acaso, mas é improvável que os valores passados de $x$ sejam úteis para prever $z$ se estiver se controlando para os valores passados de $z$, a menos que $x$ realmente cause $y$ (Stern \& Enflo, 2013).

Efetuamos testes de causalidade de Granger para cada par de variáveis na equação de cointegração (2). No entanto, como algumas das séries não são estacionárias (vide Tabela 2) apesar de serem possivelmente cointegradas, optamos por seguir o procedimento de Toda \& Yamamoto (1995) para efetuar os testes de causalidade de Granger.

A abordagem de Toda \& Yamamoto (1995) do teste de causalidade de Granger se fundamenta em um modelo VAR padrão para os níveis das variáveis, ao invés das diferenças de primeira ordem destas, 
como faz o teste convencional de causalidade de Granger. Assim, no caso de um par de variáveis, $z$ e $x$, o procedimento de Toda \& Yamamoto (1995) consiste em se estimar o modelo vetor autoregressivo (VAR) formado pelas equações (7) e (8):

$$
\begin{aligned}
& z_{t}=\alpha+\sum_{i=1}^{k} \beta_{i} z_{t-1}+\sum_{j=k+1}^{k+d} \beta_{j} z_{t-j}+\sum_{i=1}^{k} \gamma_{i} x_{t-1}+\sum_{j=k+1}^{k+d} \gamma_{j} x_{t-j}+\epsilon_{1 t} \\
& x_{t}=\omega+\sum_{i=1}^{k} \delta_{i} x_{t-1}+\sum_{j=k+1}^{k+d} \delta_{j} x_{t-j}+\sum_{i=1}^{k} \theta_{i} z_{t-1}+\sum_{j=k+1}^{k+d} \theta_{j} x_{t-j}+\epsilon_{2 t},
\end{aligned}
$$

em que $k$ é o número de defasagens e $d$ é número máximo de relações de cointegração que pode haver entre pares de variáveis na equação (2). A hipótese nula do teste na equação (7) é $H_{0}: \gamma_{1}=\ldots=\gamma_{k}=0$, ou seja, $x$ não Granger causa $z$ e na equação (8), $H_{0}: \theta_{1}=\ldots=\theta_{k}=0$, ou seja, $z$ não Granger causa $x$. Ambas são efetuadas como um teste de Wald que sob $H_{0}$ segue assintoticamente uma distribuição qui-quadrado com $k$ graus de liberdade.

A Tabela 3 apresenta os resultados dos testes Toda \& Yamamoto (1995) de causalidade de Granger para as variáveis na equação (2).

A não rejeição da hipótese de que uma variável $x$ não Granger causa uma variável $z$ e vice-versa, não necessariamente implica que não há uma relação de causalidade entre estas. De fato, o pequeno poder do teste de causalidade de Granger pode ser agravado se o número de defasagens no VAR for mal especificado (Granger, 1988), número insuficiente de observações, omissão de outras variáveis importantes e presença de não linearidades (Stern \& Enflo, 2013). Dessa forma, optamos por manter no modelo todas as variáveis em que as hipóteses nulas não foram rejeitadas em ambas as equações (7) e (8), no caso as variáveis end, end ${ }^{2}, p$, ic (vide resultados na Tabela 3). Também, optamos por manter $\Delta \%$ pib apesar de termos encontrado que $y$ Granger causa $\Delta \% p i b$, pois essa variável se mostrou pouco importante nas estimações, mas controla para o ciclo de negócios. Por fim, pelos resultados na Tabela 3 as variáveis, $t j$, iae, dummy e end $\times d u m m y$ Granger causam $y$.

Em especial, a relação unidirecional de causalidade de Granger de $t j$ para $y$ dá suporte à especificação do modelo na equação (2), pois indica que não há causalidade reversa da taxa de juros com relação à inadimplência. Ainda, fornece indícios contra a hipótese de Stiglitz \& Weiss $(1981,1983)$ segundo a qual bancos podem não aumentar a taxa de juros dos empréstimos mesmo em face de excesso de demanda por fundos, pois se assim o fazem reduzem as próprias taxas esperadas de retorno, pois elevam a probabilidade de falirem devido ao aumento na inadimplência dos tomadores de crédito (efeito risco moral e seleção adversa).

O segundo passo no procedimento ARDL teste de limites para cointegração consiste em se estimar o modelo irrestrito de correção de erros (UECM) ou, segundo Pesaran et al. (2001), um modelo "ECM condicional", que no caso do presente trabalho segue a equação (9):

$$
\begin{aligned}
\Delta y_{t}=b_{0} & +\sum_{j=1}^{q_{0}} b_{1 j} \Delta y_{t-j}+\sum_{j=0}^{q_{1}} b_{2 j} \Delta d u m m y t-j+\sum_{j=0}^{q_{2}} b_{3 j} \Delta e n d_{t-j}+\sum_{j=0}^{q_{3}} b_{4 j} \Delta e n d_{t-j}^{2} \\
& +\sum_{j=0}^{q_{4}} b_{5 j} \Delta(\text { end } \times d u m m y)_{t-j}+\sum_{j=0}^{q_{5}} b_{6 j} \Delta t j_{t-j}+\sum_{j=0}^{q_{6}} b_{7 j} \Delta p_{t-j}+\sum_{j=0}^{q_{7}} b_{8 j} \Delta i a e_{t-j} \\
& +\sum_{j=0}^{q_{8}} b_{9 j} \Delta i c_{t-j}+\sum_{j=0}^{q_{9}} b_{10 j} \Delta \Delta \% p i b_{t-j}+\sum_{j=0}^{q_{10}} b_{11 j} \Delta \Delta \% s_{t-j} \\
& +\lambda_{1} y_{t-1}+\lambda_{2} d u m m y_{t-2}+\lambda_{3} \text { end } d_{t-1}+\lambda_{4} e n d_{t-1}^{2}+\lambda_{5}(\text { end } \times d u m m y)_{t-1} \\
& +\lambda_{6} t j_{t-2}+\lambda_{7} p_{t-1}+\lambda_{8} \text { iae }_{t-1}+\lambda_{9} i c_{t-1}+\lambda_{10} \Delta \% p i b_{t-1}+\lambda_{11} \Delta \% s_{t-1}+e_{t},
\end{aligned}
$$


Tabela 3. Resultados dos teste Toda-Yamamoto de causalidade de Granger.

\begin{tabular}{|c|c|c|c|}
\hline Hipótese nula & $\begin{array}{l}\text { Termos de defasagem } \\
(k+d) \text { do teste de } \\
\text { Toda \& Yamamoto (1995) }\end{array}$ & $\chi^{2}$ & $p$-valor \\
\hline dummy não Granger causa $y$ & $13+0$ & $29,743 * * *$ & 0,005 \\
\hline y não Granger causa dummy & $13+0$ & 16,798 & 0,209 \\
\hline end não Granger causa $y$ & $12+1$ & 14,116 & 0,366 \\
\hline$y$ não Granger causa end & $12+1$ & 10,728 & 0,634 \\
\hline end $d^{2}$ não Granger causa $y$ & $9+1$ & 9,712 & 0,374 \\
\hline$y$ não Granger causa $e n d^{2}$ & $9+1$ & 5,331 & 0,805 \\
\hline end $\times$ dummy não Granger causa $y$ & $11+0$ & $19,225^{*}$ & 0,057 \\
\hline$y$ não Granger causa end $\times$ dummy & $11+0$ & 9,18 & 0,605 \\
\hline tj não Granger causa $y$ & $13+0$ & $20,438 *$ & 0,085 \\
\hline$y$ não Granger causa $t j$ & $13+0$ & 6,105 & 0,942 \\
\hline$p$ não Granger causa $y$ & $1+1$ & 0,834 & 0,659 \\
\hline$y$ não Granger causa $p$ & $1+1$ & 1,743 & 0,418 \\
\hline iae não Granger causa $y$ & $9+0$ & $15,034 *$ & 0,09 \\
\hline y não Granger causa iae & $9+0$ & 9,404 & 0,401 \\
\hline ic não Granger causa $y$ & $2+1$ & 1,823 & 0,61 \\
\hline y não Granger causa ic & $2+1$ & 1,178 & 0,758 \\
\hline$\Delta \%$ pib não Granger causa $y$ & $13+0$ & 13,034 & 0,445 \\
\hline y não Granger causa $\Delta \% p i b$ & $13+0$ & $20,467 *$ & 0,084 \\
\hline$\Delta \% s$ não Granger causa $y$ & $12+0$ & 17,327 & 0,138 \\
\hline$y$ não Granger causa $\Delta \% s$ & $12+0$ & 12,453 & 0,41 \\
\hline
\end{tabular}

Notas: ${ }^{*}=$ significativo a $10 \% ;{ }^{* *}=$ significativo a $5 \%$; e ${ }^{* * *}=$ significativo a $1 \%$.

em que $b_{0}$ é uma constante, $b_{10}, \ldots, b_{1 q 1}, \ldots, b_{110}, \ldots, b_{1 q 10}$ são parâmetros de curto prazo; $\lambda_{1}, \ldots, \lambda_{11}$ são parâmetros de longo prazo; e $e_{t}$ é um erro gerado por um processo ruído branco. Os números de termos nos somatórios em (9) podem ir de zero a $q_{0}$, de um a $q_{1}$, de um a $q_{2}$, e assim por diante, e representam a dinâmica de correção dos erros do modelo UECM.

Antes de efetuar o teste de limites para cointegração, a equação (9) é estimada por Mínimos Quadrados Ordinários (MQO) para todas as combinações possíveis de defasagens das variáveis, com base nos valores máximos pré-estabelecidos para $q_{0}, q_{1}, \ldots, q_{10}$, o que gera um número muito grande de modelos possíveis e demanda um esforço computacional grande. Sendo assim, reduzimos as combinações possíveis de modelos ARDL (9) a serem estimados, limitando o número de regressores dinâmicos (aqueles com podem apresentar defasagens distribuídas) em cada um dos quatro modelos na Tabela 4 para as variáveis discriminadas na terceira linha da Tabela 4. Como critério geral, mantivemos como regressores dinâmicos as variáveis end, end ${ }^{2}, t j, d u m m y$, end $\times d u m m y$ e $\Delta \% s$. As estruturas ARDL dos modelos são apresentadas na Tabela 4 e foram selecionadas de modo a minimizar o Critério de Informação de Akaike (AIC). 


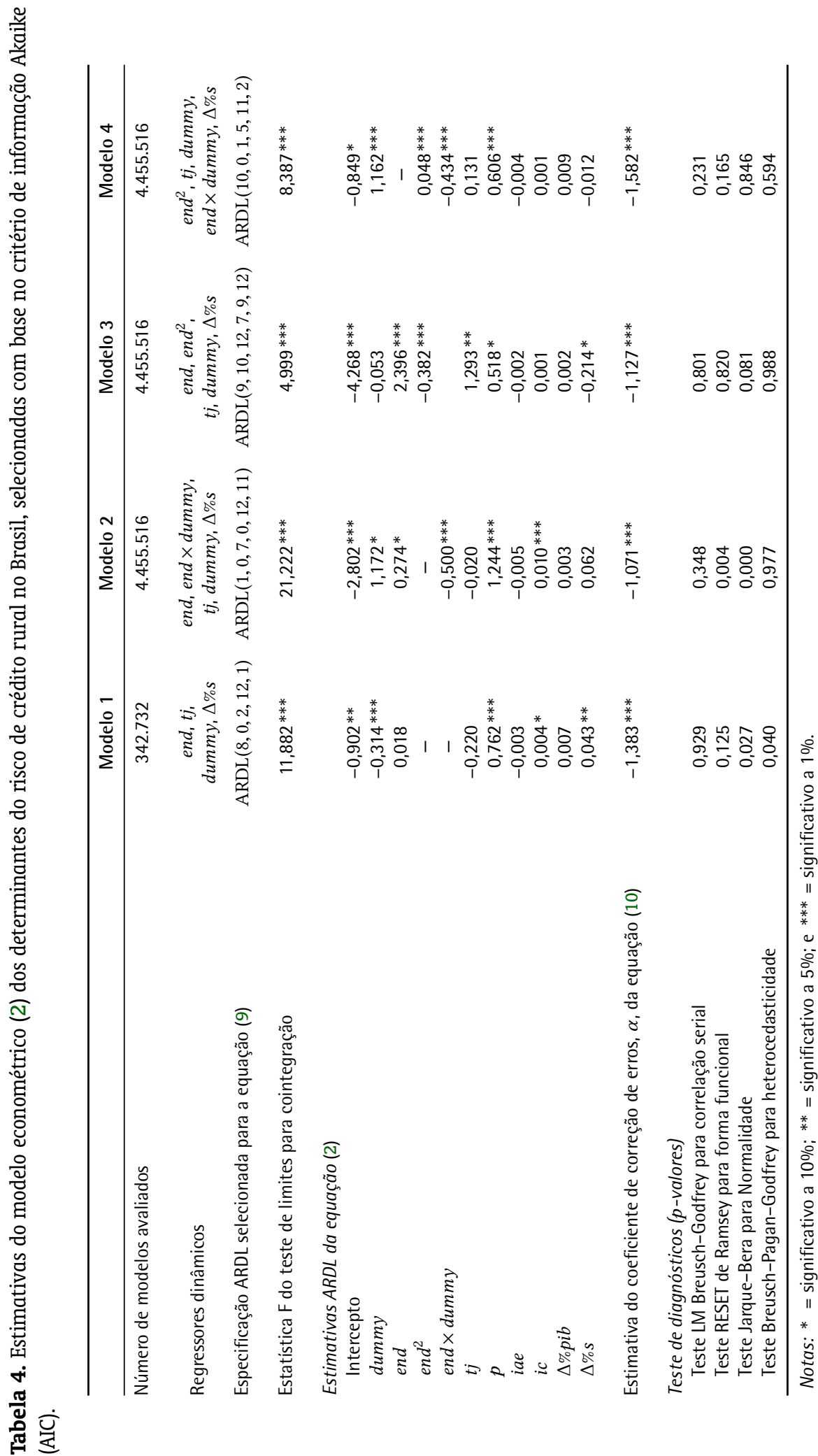

RBE Rio de Janeiro v. 71 n. 1/p. 67-91 Jan-Mar 2017 
Como os termos $\lambda_{1}, \ldots, \lambda_{11}$ na equação (9) compõem a relação de longo prazo ou cointegração entre as variáveis, o teste de limites para cointegração é um teste de Wald da hipótese nula conjunta $H_{0}: \lambda_{0}=\lambda_{1}=\cdots=\lambda_{11}=0$ contra a hipótese alternativa de que $H_{0}$ é falsa, ou seja, de que há uma relação de longo prazo ou cointegração entre as variáveis do modelo. A estatística F calculada é comparada com dois valores críticos sugeridos por Pesaran et al. (2001). Um valor é obtido assumindo que todas as variáveis são $\mathrm{I}(0)$ e o outro, assumindo que todas são I(1). Se o valor da estatística $\mathrm{F}$ excede o valor crítico superior, rejeita-se a hipótese nula de que as variáveis não são cointegração independentemente de estas serem I(0) ou I(1); se o valor da estatística F ficar abaixo do valor crítico inferior, a hipótese nula de não cointegração não é rejeitada; e se estiver dentro do intervalo formado pelos valores críticos, o teste é inconclusivo (Pesaran et al., 2001).

O terceiro passo, se o teste de limites leva à conclusão de que há uma relação de cointegração entre as variáveis do modelo, consiste em se estimar por MQO um modelo ECM convencional, utilizando as estimativas do modelo ARDL selecionado no passo 2, segundo a equação (10):

$$
\begin{aligned}
\Delta y_{t}=b_{0} & +\sum_{j=1}^{q_{0}} b_{1 j} \Delta y_{t-j}+\sum_{j=0}^{q_{1}} b_{2 j} \Delta d u m m y t-j+\sum_{j=0}^{q_{2}} b_{3 j} \Delta e n d_{t-j}+\sum_{j=0}^{q_{3}} b_{4 j} \Delta e n d_{t-j}^{2} \\
& +\sum_{j=0}^{q_{4}} b_{5 j} \Delta(\text { end } \times d u m m y)_{t-j}+\sum_{j=0}^{q_{5}} b_{6 j} \Delta t j_{t-j}+\sum_{j=0}^{q_{6}} b_{7 j} \Delta p_{t-j}+\sum_{j=0}^{q_{7}} b_{8 j} \Delta i a e_{t-j} \\
& +\sum_{j=0}^{q_{8}} b_{9 j} \Delta i c_{t-j}+\sum_{j=0}^{q_{9}} b_{10 j} \Delta \Delta \% p i b_{t-j}+\sum_{j=0}^{q_{10}} b_{11 j} \Delta \Delta \% s_{t-j} \\
& +\alpha E C M_{t-1}+w_{t},
\end{aligned}
$$

em que $E C M_{t-1}$ é a série defasada em um tempo dos resíduos obtida na estimação MQO do modelo ARDL selecionado no passo 2; e $\alpha$ é a velocidade de ajustamento de volta ao equilíbrio de longo prazo após um choque de curto prazo. Com base nesse modelo ECM convencional estimado obtêm-se as estimativas dos parâmetros de longo prazo $\beta_{0}, \ldots, \beta_{10}$ na equação (2), as quais são apresentadas na Tabela 4.

Os resultados na Tabela 4 mostram que o coeficiente da variável de interação, end $\times$ dummy, é significante a 5\% no Modelo 2 que aninha o Modelo 1, assim mostrando a necessidade de se manter esta variável nos modelos. Já a significância da variável end ${ }^{2}$ no Modelo 3 a 1\% indica que essa variável também deve ser mantida. Assim, o Modelo 4 que inclui $e n d^{2}$ e end $\times d u m m y$ indica ser de fato necessário manter estas duas variáveis, o que o credencia como modelo a ser escolhido. Finalmente, é necessário que os erros do modelo sejam serialmente independentes senão as estimativas dos parâmetros não serão consistentes devido à presença de valores autoregressivos/defasagens da variável dependente que aparecem como regressores nos modelos estimados. Nesse tocante, o Modelo 4 foi escolhido para servir como base para as nossas análises, pois também passou todos os testes de diagnósticos apresentados na Tabela 4, os quais indicam que os seus erros são homocedásticos, não autocorrelacionados e normalmente distribuídos e, assim, independentes, e que o Modelo 4 está corretamente especificado. Ainda, a estatística $\mathrm{F}$ do teste de limites no Modelo 4 é 8,387, o que excede o valor crítico do teste para o limite superior a $1 \%$ de significância, o que indica que há relação de cointegração ou longo prazo entre as variáveis.

Com base no Modelo 4, o efeito estimado do endividamento na inadimplência é

$$
\frac{\partial \hat{y}}{\partial e n d}=0,096 \text { end }-0,434 \text { dummy, }
$$

tal que quando não há renegociações da dívida $(d u m m y=0)$, o aumento no endividamento aumenta a inadimplência devido à redução na capacidade de pagamento no SNCR. No entanto, a estimativa do efeito 
indireto do endividamento na inadimplência é $-0,434$, indicando que a renegociação induz à redução da inadimplência com o maior endividamento (efeito risco moral). De fato, quando há renegociação o efeito estimado do aumento do endividamento na inadimplência é $-0,434+0,096 \times$ end e, assim, negativo se o endividamento está abaixo de 4,52\%. Níveis de endividamento menores que 4,52\% ocorrem em $95 \%$ dos meses na amostra como um todo e em $96 \%$ dos meses em que há renegociações da dívida, o que confirma a hipótese de que há risco moral provocado pelo endividamento no SNCR.

Como os processos políticos envolvidos nas renegociações das dívidas acabam por facilitar o pagamento da dívida rural um sinal negativo de $\partial y / \partial d u m m y$ indica diminuição na inadimplência porque a melhora na capacidade de pagamento suplanta o efeito risco moral/seleção adversa de Stiglitz \& Weiss (1981, 1983), ao passo que um sinal positivo, indica que o efeito risco moral/seleção adversa de Stiglitz e Weiss suplanta a melhora na capacidade de pagamento dos mutuários do SNCR.

Com base no Modelo 4, o efeito estimado da renegociação política da dívida rural é

$$
\frac{\partial \hat{y}}{\partial d u m m y}=1,162-0,434 \text { end },
$$

ou seja, é positivo; ou seja, o efeito risco moral/seleção adversa da renegociação suplanta a melhora da capacidade de pagamento, se o endividamento estiver abaixo de $2,68 \%$, o que ocorre em aproximadamente $20 \%$ dos meses da amostra e em $38,4 \%$ dos meses em que há renegociação da dívida rural. No entanto, se o nível de endividamento for superior a 2,678\%, o efeito estimado da renegociação é de reduzir inadimplência, possivelmente porque o perdão e facilidades concedidas aos mutuários com a renegociação suplantam o efeito risco moral/seleção adversa de Stiglitz \& Weiss $(1981,1983)$.

Os resultados também indicam que a variável taxa de juros deixa de ser importante para explicar inadimplência. $O$ fato de controlarmos para as renegociações políticas da dívida, as quais envolvem perdões de parte das dívidas e facilitações das condições de pagamento, acaba por tornar irrelevante o valor da taxa de juros. Possivelmente a taxa de juros de referência dos empréstimos no SNCR, enquanto custo do empréstimo para o tomador de recursos, é uma mera peça de ficção em um cenário de grande possibilidade de renegociações políticas da dívida.

Os resultados do Modelo 4 indicam que o setor externo (iae, ic) e as variáveis macroeconômicas $(\Delta \% p i b, \Delta \% s)$ não impactam inadimplência no crédito rural no Brasil.

Os resultados do Modelo 4 também indicam que para cada aumento ceteris paribus de $10 \%$ nos preços pagos pela agricultura em relação aos preços recebidos, $p$, há um aumento estimado de $6,06 \%$ na inadimplência no SNCR devido a perda de capacidade de pagamento dos tomadores de recursos.

O coeficiente estimado para o termo de correção de erro, $\alpha$ na equação (10), pelo Modelo 4 foi negativo e significante a $1 \%$, o que era esperado uma vez que as variáveis do modelo são cointegradas segundo o teste de limites. Assim, estima-se que 158,2\% de qualquer desequilíbrio de curto prazo da taxa de inadimplência e as demais variáveis no Modelo 4 são resolvidos muito rapidamente, em menos de um mês. Mais precisamente, em 1/1,582 =0,63 meses ou, aproximadamente, 19 dias.

\section{CONCLUSÕES}

Como discutimos na seção 2 do presente artigo, o financiamento da atividade rural é liderado pelo setor público e os subsídios foram essenciais para os ganhos de produtividade e modernização da agropecuária no Brasil (Belik, 2014; Araújo, 2011; Santos \& Braga, 2013). No entanto, o mercado de crédito rural, altamente regulamentado, parece apresentar falhas advindas das constantes renegociações da dívida rural que privilegiam tipos de mutuários e possuem regras que estimulam o não pagamento da dívida rural. Nesse sentido, a literatura consultada propõe que as renegociações da dívida rural são uma via de mão dupla. Por um lado, facilitam o pagamento dos empréstimos via alongamento de prazos, equalização das taxas de juros e aumento da liquidez do setor rural. Por outro lado, o caráter amplo e 
sistemático das renegociações geram incentivos adversos aos produtores rurais, uma vez que estes incorporam as renegociações em suas expectativas e, assim, parecem se endividar além de sua capacidade de pagamento visando, exatamente, forçar a repactuação da dívida (Távora, 2014).

Os modelos ARDL estimados no presente trabalho captam o efeito dos processos políticos de renegociações na inadimplência agregada no SNCR com uma variável dummy. Os resultados indicam que, ceteris paribus, há efeito risco moral e seleção adversa de Stiglitz \& Weiss $(1981,1983)$ devido às renegociações da dívida e que este suplanta o efeito melhora da capacidade de pagamento devido às renegociações em $20 \%$ dos meses, ocorrendo o efeito oposto nos outros $80 \%$ dos meses na amostra, quando o efeito é o de reduzir inadimplência. Ainda, a estimativa do efeito indireto do endividamento na inadimplência indica que renegociações induzem redução na inadimplência com maior endividamento (efeito risco moral), o que é explicado pelo incentivo ao endividamento como forma de induzir renegociações da dívida rural, criado com os processos políticos de renegociações das dívidas. Em suma, os resultados indicam que os processos políticos de renegociação da dívida no SNCR induzem níveis de endividamento maiores do que em um cenário sem renegociações. Além disso, as renegociações ao induzirem o risco moral e seleção adversa de Stiglitz e Weiss fazem com que o SNCR opere com níveis de inadimplência superiores aos que existiriam em cenários sem renegociações.

Em linha com as conclusões para os efeitos das renegociações políticas da inadimplência no SNCR, os resultados indicaram que a taxa de juros não é importante para explicar inadimplência no SNCR, ao se controlar para renegociações políticas da dívida nos modelos. Como estas renegociações envolvem perdões de parte das dívidas e facilitações das condições de pagamento, acabam por tornar a taxa de juros de referência dos empréstimos no SNCR, enquanto custo do empréstimo para o tomador de recursos, uma mera peça de ficção em um cenário onde há grande chance de renegociações futuras da dívida.

Os resultados indicam ainda que o setor externo e variáveis macroeconômicas relacionadas ao ciclo de negócios não impactam inadimplência no crédito rural no Brasil, mas que a relação preços pagos pela agricultura sobre os preços recebidos impacta, tal que há um aumento estimado de 6,06\% na inadimplência no SNCR para cada $10 \%$ de aumento nesta relação de índices de preços.

Finalmente, estima-se que desequilíbrios de curto prazo na relação da inadimplência e seus determinantes sejam rapidamente resolvidos, fazendo com que a relação retorne rapidamente ao equilíbrio de longo prazo em, aproximadamente, 19 dias.

Para uma investigação ainda mais detalhada dos determinantes da inadimplência do crédito rural no Brasil seria recomendável que em trabalhos futuros fossem levados em conta fatores geradores de risco idiossincrático devido às características dos contratos e características individuais dos mutuários. No entanto, para uma abordagem nesses moldes seria necessário dispor de microdados em painel que trouxessem características especificas dos empréstimos, dos mutuários e dos dados agregados da economia, nos moldes dos trabalhos de Bonfim (2009) e Louzis et al. (2012). Assim, como sugestão para pesquisas futuras que busquem mensurar os determinantes da inadimplência e risco de crédito, recomenda-se esse tipo de abordagem, ainda que a obtenção dos dados necessários a sua viabilização seja um desafio.

\section{REFERÊNCIAS BIBLIOGRÁFICAS}

Ali, A., \& Daly, K. (2010). Macroeconomic determinants of credit risk: Recent evidence from a cross country study. International Review of Financial Analysis, 19(3), 165-171. doi: 10.1016/j.irfa.2010.03.001

Araújo, P. F. C. d. (2011). Política de crédito rural: Reflexões sobre a experiência brasileira (Textos para Discussão CEPAL-IPEA N $\mathrm{N}^{0}$ 37). Brasília, DF: CEPAL. Disponível em: http://www.cepal.org/pt-br/publicaciones/28155 -politica-credito-rural-reflexoes-experiencia-brasileira

Arraes, R. A., \& Teles, V. K. (1999). Trajetória recente da inadimplência rural: Nordeste versus Brasil. Revista Econômica do Nordeste, 30(Número Especial), 402-418. Disponível em: http://www.repositorio.ufc.br/handle/ riufc/2264 
BCB. (2000). Classificação das operações de crédito do sistema financeiro. Banco Central do Brasil. Acessado em 22/11/2014: http://www.bcb.gov.br/htms/relinf/port/2000/06/ri200006b1p.pdf

BCBS - Basel Committee on Banking Supervision. (2005, July). An explanatory note on the Basel II IRB Risk Weight Functions (Relatório técnico). Basel, Switzerland: Bank for International Settlements (BIS). Disponível em: http://www.bis.org/bcbs/irbriskweight.htm

BCB - Banco Central do Brasil. (2014a). FAQ - Programa Nacional de Fortalecimento da Agricultura Familiar - Pronaf. Banco Central do Brasil. Acessado em 22/11/2014: http://www.bcb.gov.br/pre/bc_atende/port/ PRONAF.asp\# 1

BCB - Banco Central do Brasil. (2014b). Sistema Gerenciador de Séries Temporais (SGS) [Time Series Management System]. Banco Central do Brasil. Acessado em 22/11/2014: https://www3.bcb.gov.br/sgspub/localizarseries/ localizarSeries.do?method = prepararTelaLocalizarSeries

Belik, W. (2014). O financiamento da agropecuária brasileira no período recente. In A. B. Calixtre, A. M. Biancarelli \& M. A. M. Cintra (Eds.), Presente e futuro do desenvolvimento brasileiro (pp. 329-374). Brasília, DF: IPEA. Disponivel em: http://www.ipea.gov.br/portal/index.php?option=com_content\&id=23279

Bofondi, M., \& Ropele, T. (2011, March). Macroeconomic determinants of bad loans: Evidence from Italian banks (Occasional Papers $N^{0}$ 89). Rome: Banca D’Italia. Disponível em: https://www.bancaditalia.it/pubblicazioni/ qef/2011-0089/index.html

Bonfim, D. (2009). Credit risk drivers: Evaluating the contribution of firm level information and of macroeconomic dynamics. Journal of Banking \& Finance, 33(2009), 281-299. doi: 10.1016/j.jbankfin.2008.08.006

Dickey, D.A., \& Fuller, W.A. (1979). Distribution of the estimators for autoregressive time series with a unit root. Journal of the American Statistical Association, 74(366), 427-431. doi: http://www.jstor.org/stable/2286348

Engle, R. F., \& Granger, C. W. J. (1987). Cointegration and error correction: Representation, estimation and testing. Econometrica, 55(2), 251-276.

FGV-IBRE. (2014). FGVDados. Rio de Janeiro, RJ: Instituto Brasileiro de Economia (IBRE). Acessado em 22/11/2014: http://portalibre.fgv.br/main.jsp?lumChannelId=402880811D8E34B9011D92C493F131B2

Gambera, M. (2000, April). Simple forecasts of bank loan quality in the business cycle (Emerging Issues Series $\mathrm{N}^{0}$ S\&R-2000-3). Chicago, IL: Federal Reserve Bank of Chicago. Disponível em: https://www.chicagofed.org/ / media/publications/risk-management-papers/sr-2000-3-pdf.pdf

Granger, C. W. J. (1988). Some recent development in a concept of causality. Journal of Econometrics, 39(1), 199-211. doi: 10.1016/0304-4076(88)90045-0

IPEA. (2014). Ipeadata. Instituto de Pesquisa Econômica Aplicada. Disponível em: http://www.ipeadata.gov.br

Jalil, A., \& Feridun, M. (284-291). The impact of growth, energy and financial development on the environment in China: A cointegration analysis. Energy Economics, 2011(33), 2. doi: 10.1016/j.eneco.2010.10.003

Jiménez, G., \& Saurina, J. (2006). Credit cycles, credit risk, and prudential regulation. International Journal of Central Banking, 2(2), 65-98. Disponivel em: http://www.ijcb.org/journal/ijcb06q2a3.htm

Johansen, S., \& Juselius, K. (1990). Maximum likelihood estimation and inference on cointegration: With applications to the demand for money. Oxford Bulletin of Economics and Statistics, 52(2), 169-210. doi: 10.1111/j.1468-0084.1990.mp52002003.x

Koopman, S. J., Kräussl, R., Lucas, A. \& Monteiro, A. B. (2009). Credit cycles and macro fundamentals. Journal of Empirical Finance, 16(1), 42-54. doi: 10.1016/j.jempfin.2008.07.002

Louzis, D. P., Vouldis, A.T. \& Metaxas, V.L. (2012). Macroeconomic and bank-specific determinants of nonperforming loans in Greece: A comparative study of mortgage, business and consumer loan portfolios. Journal of Banking \& Finance, 36(4), 1012-1027. doi: 10.1016/j.jbankfin.2011.10.012 
Martins, A. A. B. (2010). Crédito rural: Evolução histórica, aspectos jurídicos e papel do conselho monetário nacional e do banco central do Brasil. Âmbito Jurídico, 13(73). Disponível em: http://www.ambitojuridico.com.br/ site/index.php?n_link=revista_artigos_leitura\&artigo_id $=7156$

Ouattara, B. (2004). Aid, debt and fiscal policies in Senegal [mimeo].

Pesaran, M. H., \& Shin, Y. (1999). An autoregressive distributed lag modelling approach to cointegration analysis. In S. Strom (Ed.), Econometrics and economic theory in the 20th century: The Ragnar Frisch Centennial Symposium (pp. 371-413). Cambridge University Press.

Pesaran, M. H., Shin, Y. \& Smith, R. J. (2001). Bounds testing approaches to the analysis of level relationships. Journal of Applied Econometrics, 16(3), 289-326.

Phillips, P. C. B., \& Perron, P. (1988). Testing for a unit root in time series regression. Biometrika, 75(2), 335-346. doi: 10.1093/biomet/75.2.335

Santos, R. B. N. d., \& Braga, M.J. (2013). Impactos do crédito rural na produtividade da terra e do trabalho nas regiões brasileiras. Economia Aplicada, 17(3), 299-324. doi: 10.1590/\$1413-80502013000300004

Silvestrini, A. D., \& Lima, R. A. S. (2011). Securitização da dívida rural brasileira: 0 caso do Banco do Brasil de 1995 a 2008. Revista de Economia e Sociologia Rural, 49(4), 1021-1050. doi: 10.1590/S0103-20032011000400009

Simons, D., \& Rolwes, F. (2009). Macroeconomic default modeling and stress testing. International Journal of Central Banking, 5(3), 177-204. Disponível em: http://www.ijcb.org/journal/ijcb09q3a6.htm

Stern, D. I., \& Enflo, K. (2013). Causality between energy and output in the long-run. Energy Economics, 39, 135-146. doi: 10.1016/j.eneco.2013.05.007

Stiglitz, J. E., \& Weiss, A. (1981). Credit rationing in markets with imperfect information. The American Economic Review, 71(3), 393-410. Disponível em: http://www.jstor.org/stable/1802787

Stiglitz, J.E., \& Weiss, A. (1983). Incentive effects of terminations: Applications to the credit and labor markets. The American Economic Review, 73(5), 912-927. Disponivel em: http://www.jstor.org/stable/1814662

Távora, F.L. (2014, Abril). Renegociação de dívida rural: Reflexões sobre o financiamento da agricultura brasileira (Texto para Discussão $\mathrm{N}^{0}$ 146). Brasília, DF: Senado Federal. Disponível em: https://www12.senado.leg.br/publicacoes/estudos-legislativos/tipos-de-estudos/textos-para-discussao/ td-146-renegociacao-de-divida-rural-reflexoes-sobre-o-financiamento-da-agricultura-brasileira

Toda, H. Y., \& Yamamoto, T. (1995). Statistical inference in vector autoregressions with possibly integrated processes. Journal of Econometrics, 66(1-2), 225-250. 
APÊNDICE.

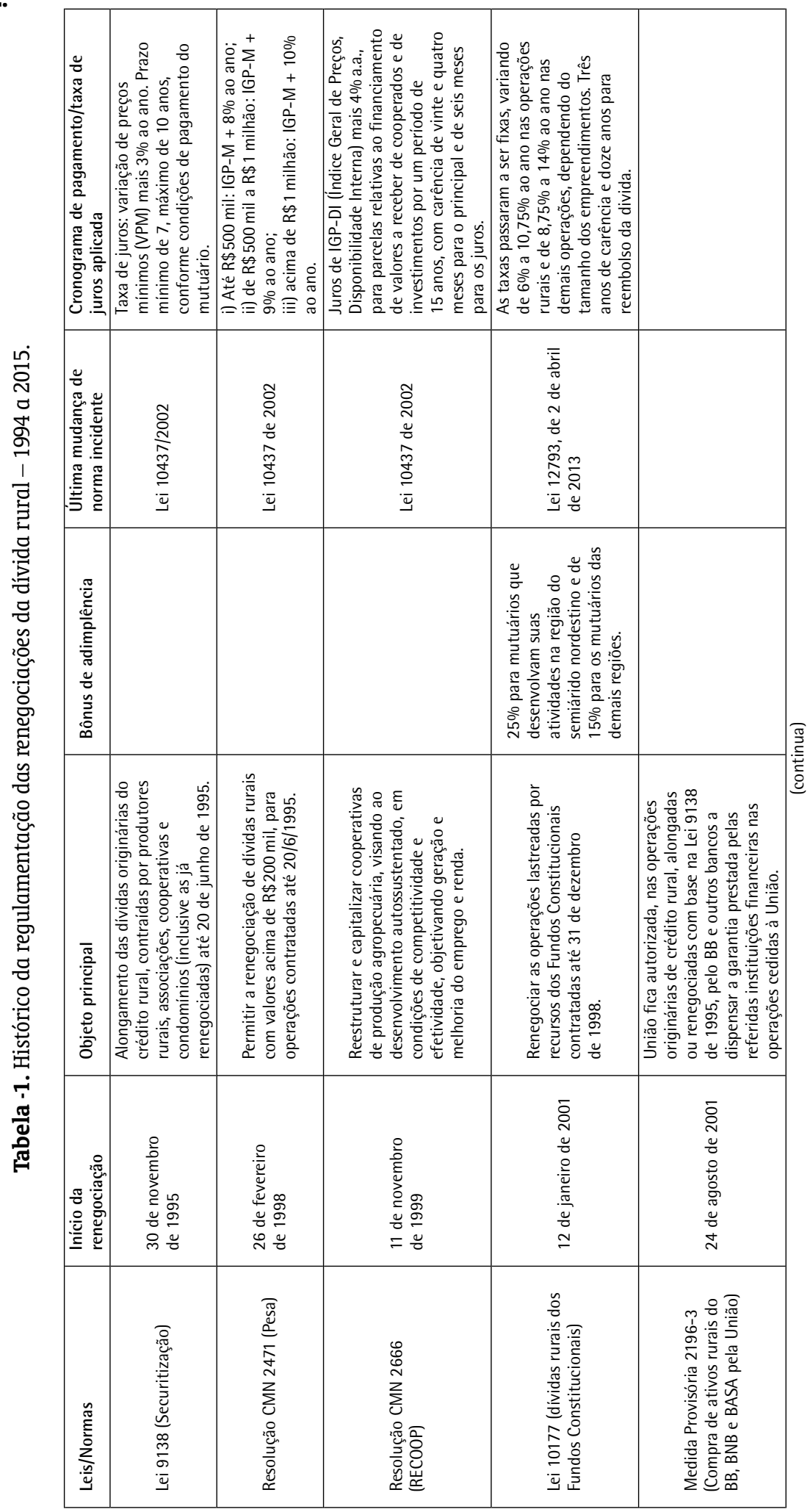




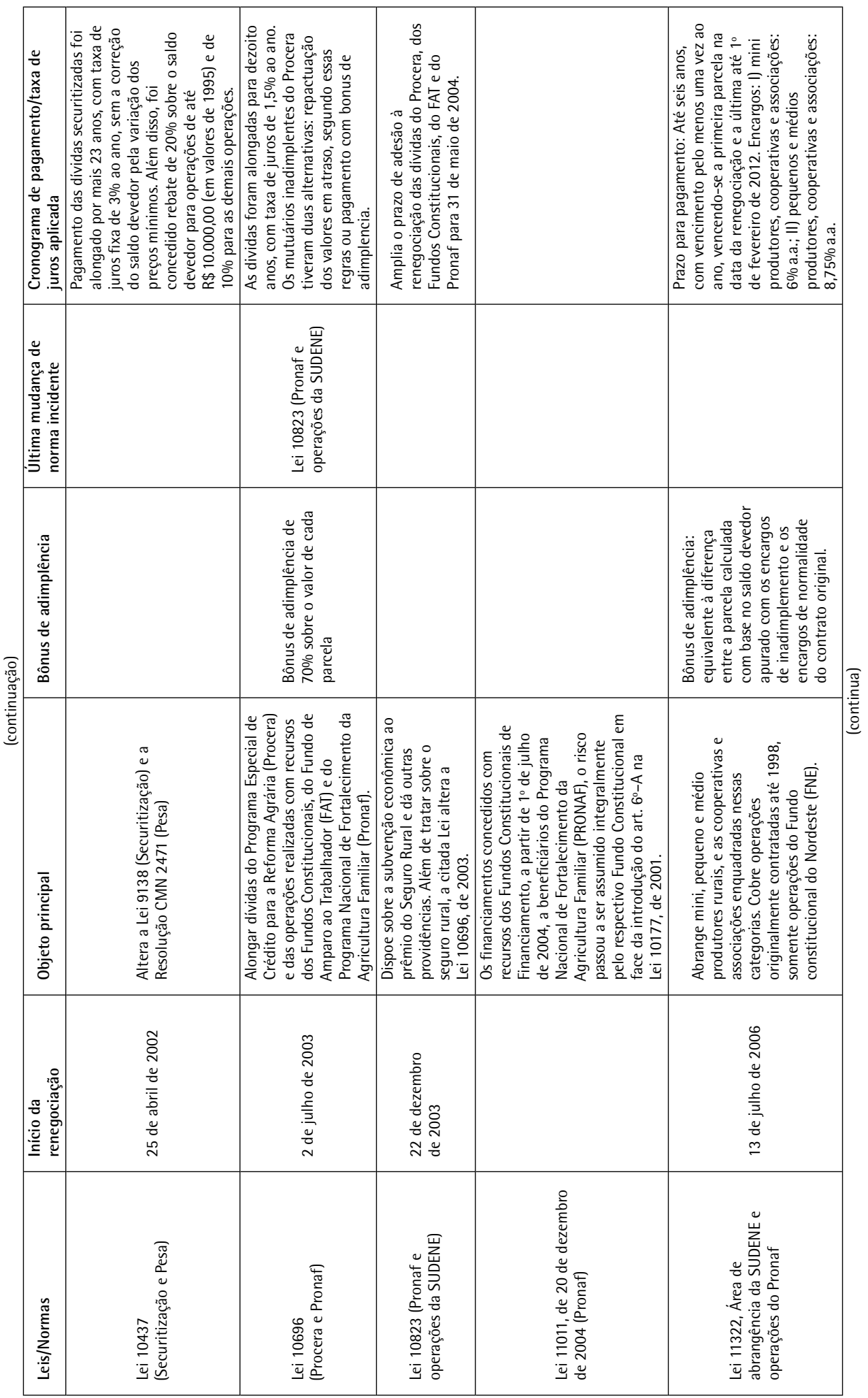

RBE Rio de Janeiro v. 71 n. 1/p. 67-91 Jan-Mar 2017 


\begin{tabular}{|c|c|c|c|c|c|}
\hline 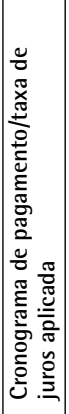 & 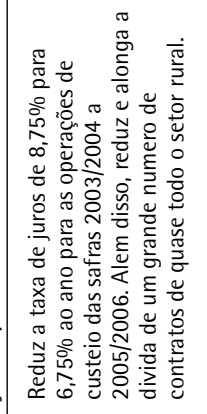 & & & & 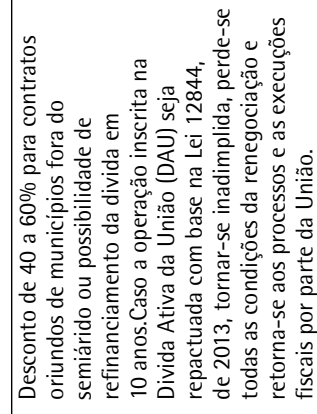 \\
\hline 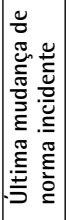 & & & 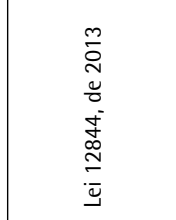 & 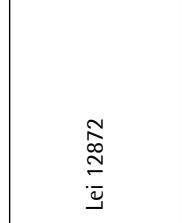 & \\
\hline 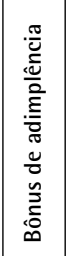 & & & & & \\
\hline 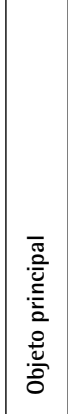 & 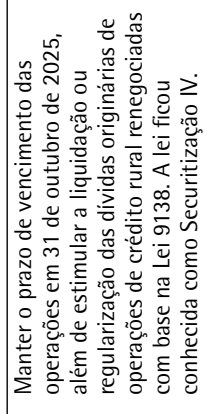 & 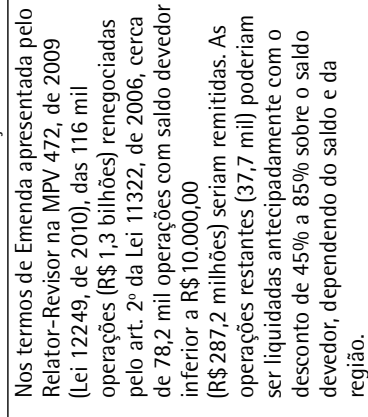 & 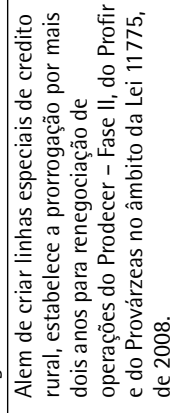 & 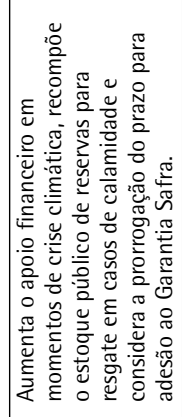 & 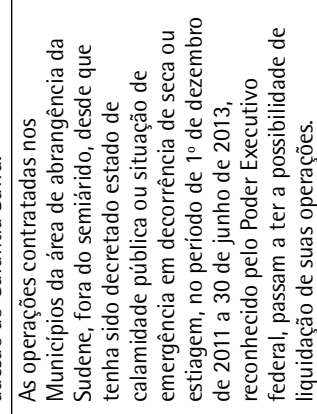 \\
\hline 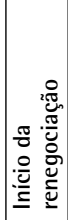 & 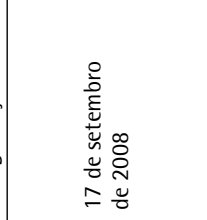 & 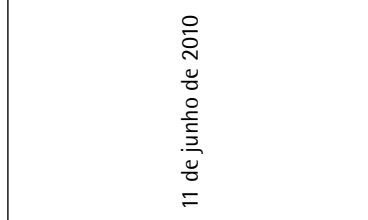 & 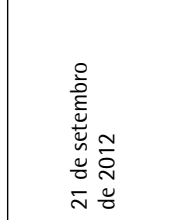 & 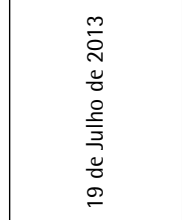 & 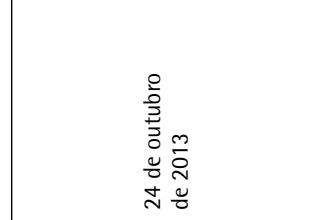 \\
\hline 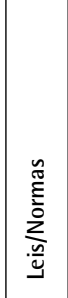 & 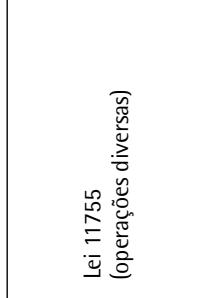 & 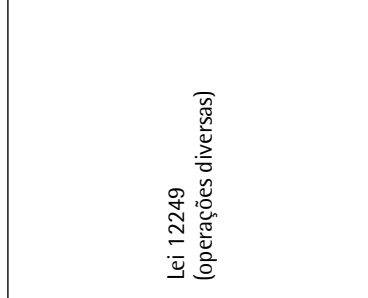 & 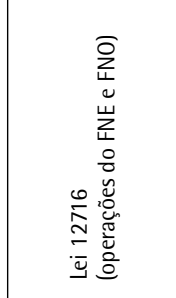 & 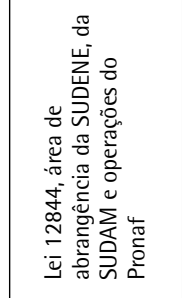 & 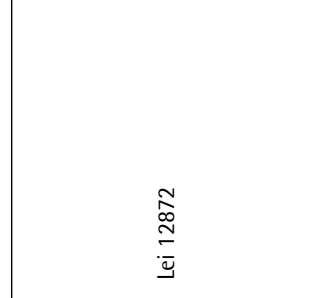 \\
\hline
\end{tabular}




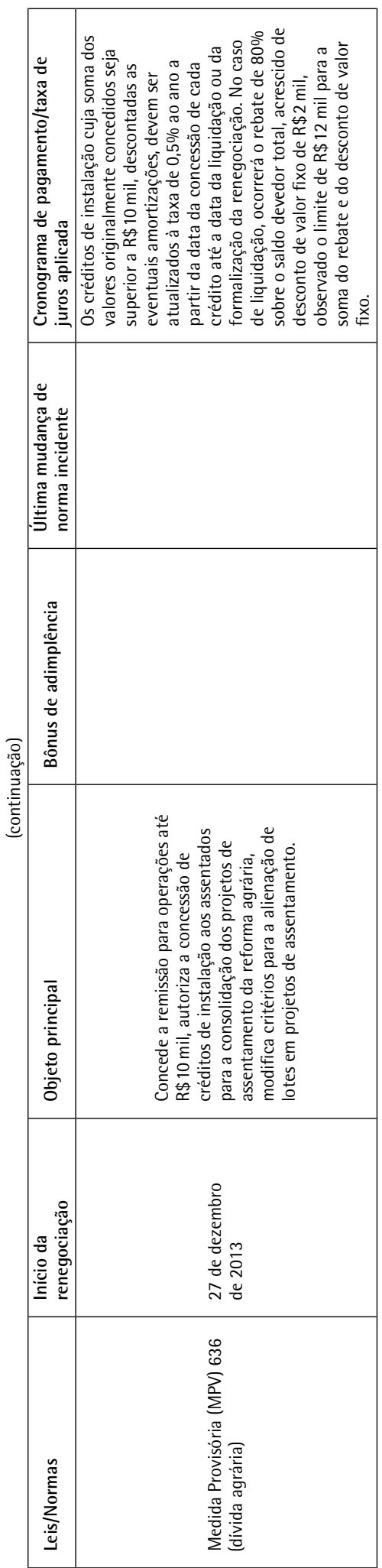

RBE Rio de Janeiro $\quad$ v. 71 n. 1/p. 67-91 Jan-Mar 2017 
ERRATA:

No artigo "Determinantes do Risco de Crédito Rural no Brasil: uma Crítica às Renegociações da Dívida Rural”, com número de DOI 10.5935/0034-7140.20170004, publicado no periódico Revista Brasileira de Economia, v. 71 n. 1, pp. 67-91, na página 75:

Onde se lia:

Assim, a variável dicotômica dummy recebe o valor um nos quatro meses subsequentes a publicação de uma lei/regulação que repactua a dívida rural ou modifica uma lei já publicada e zero nos demais períodos. A Figura 1 relaciona as Leis e Normas sobre renegociação da dívida rural e suas datas.

Leia-se:

Assim, a variável dicotômica dummy recebe o valor um nos meses anteriores e/ou subsequentes a publicação de uma lei/regulação que repactua a dívida rural ou modifica uma lei já publicada conforme como e quando a lei afeta renegociações da dívida baseandose na interpretação dos autores das informações sobre as leis analisadas em Távora (2014) e Silvestrini Lima (2011), as quais são sumarizadas na Tabela 1 do Apêndice. A variável recebe zero nos demais períodos. A Figura 1 plota a variável dummy e especifica as leis encontradas que tratam sobre renegociação ou modificam leis que o fazem.

Onde se via a Figura 1:

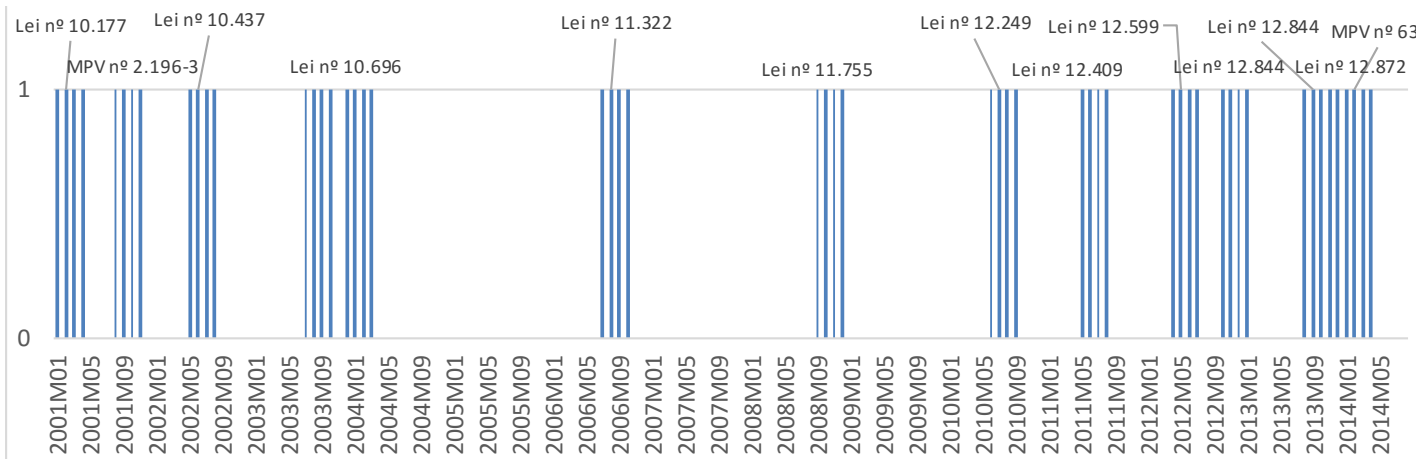

Veja-se esta Figura 1:

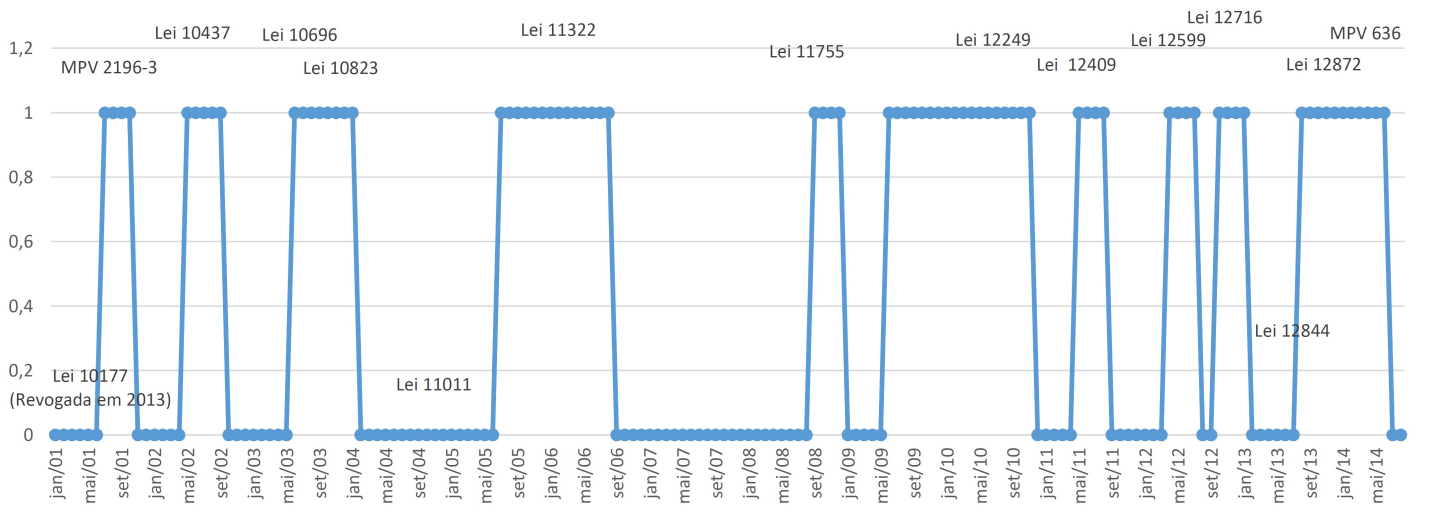

